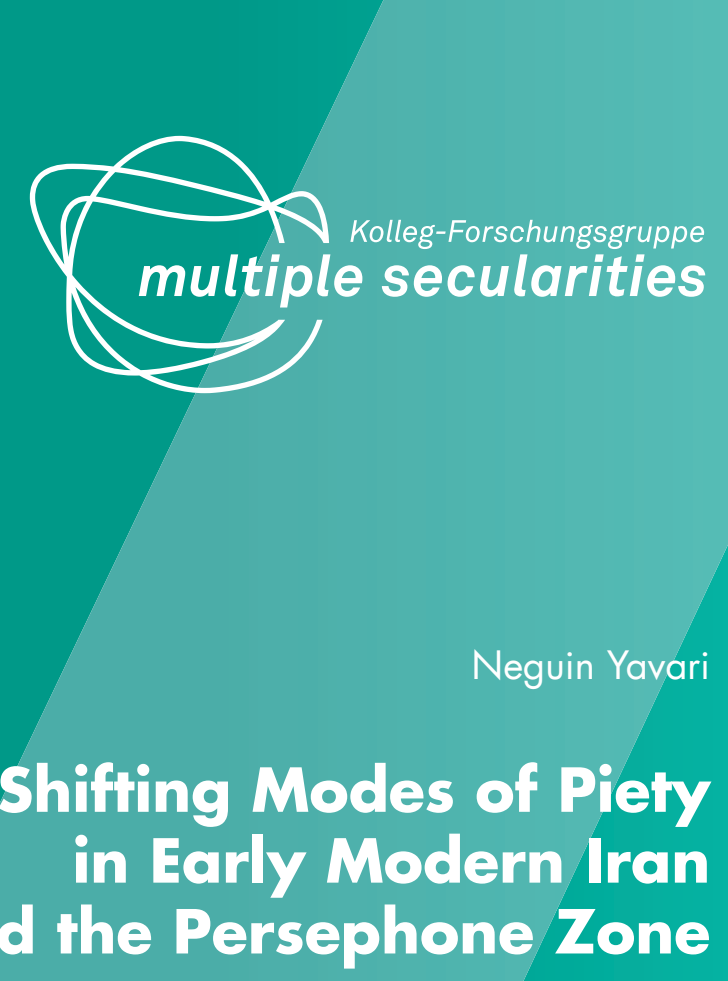

Working Paper \# 10 
Working Paper Series of the HCAS

"Multiple Secularities - Beyond the West, Beyond Modernities"

\#10: Neguin Yavari. "Shifting Modes of Piety in Early Modern Iran and the Persephone Zone."

Leipzig University, 2019.

(C) Neguin Yavari

This Working Paper has been published online and can be downloaded from www.multiple-secularities.de/publications/working-papers or ordered in print via email to multiple-secularities@uni-leipzig.de

The HCAS's Working Paper Series serves to disseminate the results of work in progress prior to publication to encourage the exchange of ideas and academic debate. Inclusion of a paper in the Working Paper Series should not limit publication in any other venue. Copyright remains with the authors.

Please cite as:

Yavari, Neguin. "Shifting Modes of Piety in Early Modern Iran and the Persephone Zone." Working Paper Series of the HCAS "Multiple Secularities - Beyond the West, Beyond Modernities" 10. Leipzig University, 2019.

Leipzig University

HCAS "Multiple Secularities - Beyond the West, Beyond Modernities"

Nikolaistraße 8-10

04109 Leipzig

Germany

The HCAS is part of Leipzig University and funded by the German Research Foundation (DFG).

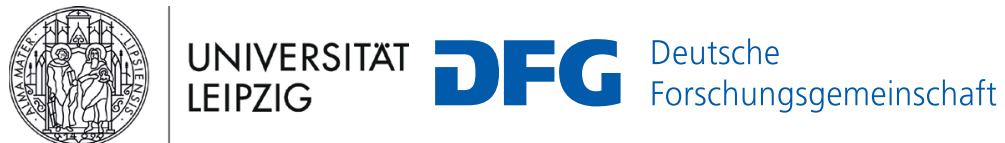




\section{Contents}

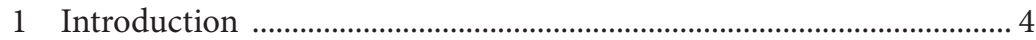

2 Mobilizing the Past: Abū 'Alī al-Fārmadhī _......................................... 5

3 The Performative Regard of Religious Discourse .................................. 9

4 Forging a Context of One's Own .............................................................. 13

5 Contextualizing Old Divides in the New Piety ....................................... 18

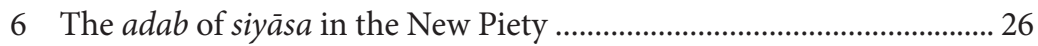

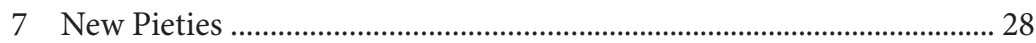

8 Global New Pieties .................................................................................. 31

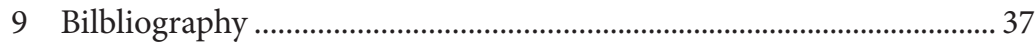





\title{
Shifting Modes of Piety in Early Modern Iran and the Persephone Zone
}

\begin{abstract}
If any one thing marks early modern history, it is religious transformation. Confessional and pietist movements, both European firsts, are prominent examples of such catalysts for change. ${ }^{1}$ In large parts of the Islamic world in the $15^{\text {th }}$ and $16^{\text {th }}$ centuries, it was Sufi piety that carried the day. The historiographical record reveals strikingly new imaginaires and novel modes of connectivity to the past. The focus in this paper is on the manifold ways in which new forms of religiosity redefined the landscape of politics in the eastern Islamic world. It traces invocations of the past in Fakhr al-Dīn Kāshifî̀s (d. 1532) Rashaḥāt 'ayn al-ḥayāt ${ }^{2}$ (Sprinklings from the Fountain of Life), a $16^{\text {th }}$-century collected biography of Naqshbandi Sufi masters, to argue that the classificatory schema adopted by the author reveals a template of secularity that marks a significant departure from past manners of adherence.
\end{abstract}

1 On religious change rather than incremental secularism as the engine of change in early modern Europe, see Jonathan Sheehan, "Enlightenment, Religion and the Enigma of Secularization: A Review Essay," American Historical Review 108, no. 4 (2003); on parallels between modern ( $18^{\text {th }}-19^{\text {th }}$ century) Sufism and American pietism, see Albrecht Hofheinz, "Illumination and Enlightenment Revisited, or: Pietism and the Roots of Islamic Modernity," Lecture delivered at the University of Bergen, 1996, http://folk.uio.no/albrech/ Hofheinz_IllumEnlightenment.pdf; and for confessionalization as the impetus for state formation, see Heinz Schilling, Early Modern European Civilization and its Political and Cultural Dynamism (Lebanon, NH: University Press of New England, 2008).

2 Mawlānā Fakhr al-Dīn al-Ṣafī 'Alī b. Ḥusayn Wāi’ẓ Kāshifî, Rashahāat 'ayn al-ḥayāt, ed. and intr. 'Ali Asghar Mu'iniyan, 2 vols (Tehran: Bunyad Nikukari Nuriyani, 1977); Arabic translation as 'Alī b. al-Husayn al-Kāshifī al-Ṣafī, Tarjamat Rashahhạt 'ayn al-ḥayāt, tr. Muhammad Murad b. 'Abd Allah al-Qazani (Mecca: Matbáa al-Muhammadiya, 1882 or 1883); English translation as Mawlana Ali ibn Husain Safi, Beads of Dew form the Source of Life, tr. Muhtar Holland (Oakland Park, CA: Al-Baz Publishers, 2001). On the manuscript history of the text, see H. Beveridge, "The Rashahāt-i 'Ain al-Hayāt (Tricklings from the Fountain of Life)," Journal of the Royal Asiatic Society 48, no. 1 (1916). "Sprinklings from the Fountain of Life" is Nile Green's translation, see "The Dilemmas of the Pious Biographer: Missionary Islam and the Oceanic Hagiography," Journal of Religious History 3, no. 4 (2010): 386. For more on the author, see Jürgen Paul, "Alī b. Husayn al-Wā'iz al-Kāshifî,” in Encyclopaedia of Islam, THREE, ed. Kate Fleet, Gudrun Krämer, Denis Matringe, John Nawas, Everett Rowson, 2009. 


\section{Introduction}

In the standard iteration that governs the history of Sufi movements, the altered social and political landscape brought about by the Mongol invasions which began in the early $13^{\text {th }}$ century is regarded as the impetus for their flourishing. In that narrative, a mystical dimension to Islam was born sometime late in the $9^{\text {th }}$ century, and developed as a spiritual alternative to the legalistic Islam of the ' $u$ lam $\vec{a} .{ }^{3}$ On the political register, the flourishing phase was coeval with the fall of the Abbasids, a protracted process that began in the mid- $9^{\text {th }}$ century and lasted until the Mongol invasions, and the ensuing freefall that lasted from the mid- $13^{\text {th }}$ to the mid- $18^{\text {th }}$ century, when colonial interventions derailed indigenous modes of social, political and economic life and reset the clock. Told as such, the history of the Islamic world in the contemporary period is severed from that which transpired in the pre-colonial past. If Sufi movements and currents dominated large swathes of the Islamic world in the $16^{\text {th }}$ and $17^{\text {th }}$ centuries, they are mostly absent from histories of the modern Islamic world, the contours of which are held to have been determined by the encounter with Europe beginning in the 1800 s, rather than by currents and developments that may have percolated in the region over long centuries. ${ }^{4}$

In the larger study of which this paper is a part, I suggest a recasting of that conventional narrative, and the periodization schema that accompanies it - a central component of which is the erasure of an early modern phase from Islamic history. Here, however, the focus is on two specific dimensions: the broader, more historicized context and the instrumentalization of the past

3 For a history of that scholarship see Nile Green, Sufism: A Global History (Chichester: Wiley-Blackwell, 2012), 1-124.

4 Devin DeWeese has come to much the same conclusion regarding Sufi movements in Central Asia in the $16^{\text {th }}$ and $17^{\text {th }}$ centuries, see Devin DeWeese, "Re-Envisioning the History of Sufi Communities in Central Asia: Continuity and Adaptation in Sources and Social Frameworks, $16^{\text {th }}-20^{\text {th }}$ Centuries," in Sufism in Central Asia: New Perspectives on Sufi Traditions, $15^{\text {th }}-21^{\text {st }}$ Centuries, ed. Devin DeWeese and Jo-Ann Gross (Leiden: Brill, 2018). For a historiographical discussion of early modern Sufism, see Rachida Chih, "Discussing the Sufism of the Early Modern Period: A New Historiographical Outlook on the Tariqa Muhammadiyya," in Sufism East and West: Mystical Islam and Cross-Cultural Exchange in the Modern World, ed. Jamal Malik and Saeed Zarrabi-Zadeh (Leiden: Brill, 2019). For more on the historiography of the early modern period in the Islamic world, see Justin Stearns, "Writing the History of the Natural Sciences in the Pre-modern Muslim World: Historiography, Religion and the Importance of the Early Modern Period," History Compass 9, no. 12 (2011). 
to legitimate a new religious ethos, and the performative regard of religious discourse that seeks to effect political change, both of which are exemplified in the text under consideration. I will begin with an examination of the deliberate rooting of Naqshbandī history in earlier debates and developments in Kāshifìs $16^{\text {th }}$-century collected biography. The performative regard of Sufi discourse, and the perlocutionary force of Kāshifîss genealogical approach and the architectural layout of his text is the subject of the second and third sections. The focus in the remaining sections is on several aspects of the new Sufi piety that lords over the religious landscape of the eastern Islamic world in the early modern period, including its novel approach to sectarian affiliation, its proximity to power, its explicit recognition of the pursuit of common good and the preservation of public peace as the prerogatives of religion, its adoption of Persian as the lingua franca of the new piety, and its emphasis on individual piety. The conclusion attends to the question of a global early modern context to the new piety.

\section{Mobilizing the Past: Abū ‘Alī al-Fārmadhī}

There may have been ascetic, pietist, or Sufi luminaries, and even spiritual communities that coalesced around them since the earliest days of Islam, but the political engagement of the Sufi reformation that altered the landscape of the Islamic world had its roots in the political crisis that engulfed the Islamic domains in the $11^{\text {th }}$ century. At that critical juncture, it had become increasingly clear that the de facto formula for Abbasid rule - a caliph in Baghdad, and one or several strongmen, usually Turks, holding the empire together - could no longer be sustained. Resolving the crisis and pushing back against attempts to resuscitate the caliphate with inoperable notions of Islamic legitimacy attracted the energies of intellectuals from all walks of life. At stake was the very scope and purpose of government in a properly ordained Islamic society.

On the social register, the $11^{\text {th }}$ century witnessed an intensification of factional violence, between Hanbalī Sunnis and Shi'is in Baghdad. In the greater Khurasan region in the east, which is our geographical focus, however, sectarian strife was inter-Sunni, between Ḥanafīs and Shāfi îs. It was in this context - of increasing intransigence and frequent outbreaks of violence - that Sufism gradually rose to prominence, thanks to its robust 
and explicitly anti-sectarian stance. ${ }^{5}$ As such, it also provided support in the prescient anti-sectarian policies enacted by statesmen such as Nizām al-Mulk (d. 1092), the fabled $11^{\text {th }}$-century vizier who ruled for three decades over the Saljūq empire in the sultan's stead.

According to medieval sources from an astonishing array of ideological positions, the vizier's true legacy was his enduring political vision, marked by pragmatism, compromise, and the fostering of durable institutions. Of the latter, the Nizāmiyya schools dedicated to the propagation of Shāfi $\bar{i}^{\prime}$ law and Asharī theology, founded and funded by the great vizier, are the best known. Although he patronized leading 'ulamä' from a host of legal and theological backgrounds, his own writings as well as other medieval sources testify to his singular attachment to Sufi notables and institutions, his chief allies in the denouncement of sectarian partisanship. Many of the Sufi masters that dominated the intellectual landscape of the post-Mongol period, especially in Iran, began their careers at a Nizāmiyya school. ${ }^{6}$ This is in stark contrast to the dearth of notable jurists associated with the schools in later centuries. ${ }^{7}$

The luminaries in the story of Sufi ascendancy in $11^{\text {th }}$-century Khurasan are well-known: Abū al-Qāsim al-Qushayrī (d. 1072), Abū Ḥāmid al-Ghazzālì (d. 1111), and to a lesser extent, Imām al-Ḥaramayn al-Juwaynī

5 On Sufi anti-sectarianism in the 11th century, see Neguin Yavari, Future of Iran's Past: Niz̄ām al-Mulk Remembered (New York: Oxford University Press, 2018), 118-25; and on Qushayrîs politics and theology, see Martin Nguyen and Matthew Ingalls, eds., "Al-Qushayrī and His Legacy," Special Issue, Journal of Sufi Studies 2, no. 1 (2013).

6 Apart from al-Fārmadhī who was associated with the Niz̄āmiyya in Nīshāpūr during Niẓām al-Mulk's lifetime, and al-Ghazzālī and Ghujduwānī who turned to Sufi practice following a Nizāmiyya career, 'Abd al-Rahmān Jāmī (d. 1492) was educated at the Nizạamiyya in Herat, and Abū al-Najīb Suhrawardī (d. 1168) was appointed as mudarris to the Nizāmiyya in Baghdad in 1150 by the Saljūq ruler Mas'ūd (r. 1134-52), to mention but a few of the best known among them. For the role played by madrasas in the propagation of Sufi teachings and extra-curricular activities in Baghdad, see Erik S. Ohlander, Sufism in an Age of Transition: 'Umar al-Suhrawardì and the Rise of the Islamic Mystical Brotherhoods (Leiden: Brill, 2008), 34-42, 79.

7 On the Nizāmiyya schools, see Yavari, Future of Iran's Past, 90-94; Michael Chamberlain, Knowledge and Social Practice in Medieval Damascus, 1190-1350 (Cambridge: Cambridge University Press, 1994), 69-90; and on the disconnect between the Nizāmiyyas and the religious or administrative elite of the period, see Vanessa van Renterghem, "Les élites dans le monde arabo-musulman médiéval: l'exemple de Baghdad sous les Seldjoukides," Hypothéses 1 (2001); and Daphna Ephrat, "Religious leadership and Associations in the Public Sphere of Seljuk Baghdad," in The Public Sphere in Muslim Societies, ed. Miriam Hoexter, Shmuel N. Eisenstadt and Nehemia Levtzion (Albany: State University of New York Press, 2002). 
(d. 1085). Extensive reference is also made to the fame and stature of Abū 'Alī al-Fārmadhì (d. 1084), and his multifarious connections to key figures in the period. Despite this, scant attempt has been made to assess such references and explain the significance of his impact. Looking at contemporary sources, a historian in search of the Sufi master and madrasa instructor would have to surmise that he was often mentioned but little known. Nothing of substance has survived from his writings either, although it should be noted that particularly in the case of Sufis in earlier periods, word of mouth was often used in place of the written word.

Al-Fārmadhī is known to have shunned power, but the biographies of Nizām al-Mulk, including the account of the noted genealogist and hadith scholar al-Fārisī (d. 1134), record in abundance the Sufi master's close interactions with the vizier, who served for a while as khädim (superintendent) at al-Fārmadhīs lodge (khānaqāh). ${ }^{8}$ Al-Fārisī was intricately connected with al-Fārmadhîs circle of friends: his mother was the daughter of al-Qushayrī, he studied jurisprudence with al-Juwaynī, and recited hadìth on the authority of al-Fārmadhī. It is reported by Ibn al-Athīr (d. 1233) that whenever al-Qushayrī and al-Juwaynī visited Nizāam al-Mulk, he would rise to greet them. Yet when al-Fārmadhī called on him, he would stand up and offer him his own seat. When questioned about this, the vizier responded:

The former two and their like praise me for that which I do not possess, and their words make me arrogant and vain. Al-Fārmadhī mentions the flaws in my soul and how much I am living in injustice, and it makes me refrain from much of what I am. ${ }^{9}$

If al-Fārmadhī shunned power at all, he did it not in terms of withdrawing from earthly concerns or avoiding encounter with power, but rather, in

8 Al-Ḥāfiz Abū al-Ḥasan 'Abd al-Ghāfir b. Ismāīil al-Fārisī, "Ta’rīkh al-Nīsābūr: almuntakhab min al-siyāq," in The Histories of Nishapur, ed. Richard Frye (London: Mouton, 1965), f. 121, r + v; and Ibrāhīm b. Muhammad al-Șarīfīnī (d. 1243-44), Al-Halqah al-ülā' min ta'rīkh Nìsābūr: al-muntakhab min al-siyāq ta'lîf Abū Hasan 'Abd al-Ghāfir b. Ismā'îl al-Fārisī, ed. Muhammad Kazim al-Mahmudi (Qum: Jama'at al-Mudarrisin fi al-Hawzah al-'Ilmiyah, 1983), 600.

9 Ibn al-Athīr, 'Izz al-Dīn Abū al-Ḥasan, The Annals of the Saljūq Turks, transl. and ann. D. S. Richards (London: Routledge, 2002), 257. The same story is found in Abu al-Faraj 'Abd al-Raḥmān b. al-Jawzī, Al-Muntazam fì ta'rīkh al-mulūk wa al-'umam (Hyderabad-Deccan: Osmania Oriental Publishers, 1939-41), XVI, 303; and Shams al-Dīn Abū al-Muzaffar Yūsuf b. Qizughlī Sibț b. al-Jawzī, Mir'āt al-zamān fì tárīkh al-àyān, ed. Salman al-Juburi (Beirut: Dar al-Kutub al-'Ilmiyya, 2013), XIII, 207. 
drawing on his spiritual capital to critique power. And why was he singularly important to Nizāam al-Mulk’s heart?

The historical import of al-Fārmadhī appears in the full light of day in the collected biographies/histories of the $15^{\text {th }}$ century. The Naqshbandi master, Nūr al-Dīn 'Abd al-Raḥmān Jāmīs (d. 1492) ${ }^{10}$ collected biography of Sufi notables, Nafaḥāt al-uns, for example, offers a slightly more textured portrait. We learn that al-Fārmadhī had first-rate teachers. He was first a disciple of Abū Sa īd Abū al-Khayr (d. 1049), ${ }^{11}$ and then studied with al-Qushayrī. Even such illustrious instructors did not sufficiently quench his thirst for learning. Al-Fārmadhī’s search for "someone to take him beyond where he was led him to Kurragānī (d. 1073 or 1077), who took him on first as a tutee, and then a son-in-law." ${ }^{12}$

There is yet another valence to al-Fārmadhîs lore that sets him apart from his peers. According to al-Dhahabī, quoting al-Fārisī, al-Fārmadhī was unique among his Sufi peers for his mode of tadhkir ${ }^{13}$ a form of Sufi devotion in which the worshipper is absorbed in the rhythmic repetition of God's name and his attributes. Although al-Fārisī does not elaborate on the matter, his privileged status as an attendee of al-Fārmadhīs h hadìth sessions, lends credence to the claim.

Overall, the later recollections of al-Fārmadhì point to a legacy that was conjured up retroactively. A few centuries after al-Fārmadhîs death, as institutionalized Sufism gained ground, so too did his fame and reputation. ${ }^{14}$ This may perhaps explain the exceptional favor he carried with Nizām alMulk. The vizier desired effective rule, which in turn demanded justice. As such, in the hyper-sectarian milieu of $11^{\text {th }}$-century Iran, unsectarianism

10 Hamid Algar, Jāmī (Delhi: Oxford University Press, 2013); and Jawid A. Mojaddedi, The Biographical Tradition in Sufism: The tabaqāt genre from al-Sulamì to Jāmì (Richmond, Surrey: Curzon Press, 2001).

11 Muhammad b. al-Munawwar, Asrār al-tawhìd, ed. Muhammad Rida Shafíi-Kadkani (Tehran: Agah, 1987), I, 118-20, 180-81.

12 Nūr al-Dīn 'Abd al-Raḥmān Jāmī, Nafahạāt al-uns min ḥaḍarāt al-quds, ed. Mahmud 'Abidi (Tehran: Ittila'at, 1991), 318-20.

13 Shams al-Dīn b. Muhammad al-Dhahabī, Siyar a 'lām al-nubalā', ed. S. al-Arna’ut and H. al-Asad (Beirut: Risala, 1984), XVIII, 565-66.

14 Al-Fārmadhì was not the only Sufi master who grew in splendor with the passage of time. Farīd al-Dīn 'Ațțār (d. 1221), the famous composer of Manțiq al-țayr and other masterpieces, "was hardly known as a poet in his own lifetime [...] and his greatness as a mystic, a poet, and a master of narrative was not discovered until the $9^{\text {th }} / 15^{\text {th }}$ centuries;" see Benedikt Reinert, "Ațtār, Farīd al-Dīn," Encyclopaedia Iranica Online, accessed June 4, 2019 [1987]. http://www.iranicaonline.org/articles/attar-farid-al-din-poet. 
emerged as a cornerstone of Nizām al-Mulk's political views. ${ }^{15}$ In that quest, the Sufis were among his best allies, and among the Sufis the vizier proffered special favor on those who shared his vision, and were keen on fostering institutions and lasting policies. Much later the Naqshbandīs chose a posthumous alliance with al-Fārmadhī, with whom they shared not just a worldview, but a desire to put that worldview into action and fashion society and politics along its lines as well.

\section{The Performative Regard of Religious Discourse}

The performative regard in Sufi cosmology in the $11^{\text {th }}$ century, along with the rise of Sufi movements in tandem with the fall of Abbasid power, has not gone unnoticed. ${ }^{16}$ As various Sufi communities stepped up to the plate and assumed certain functions of governance abandoned by the dysfunctional caliphate, Sufi manuals adopted multi-dimensional metaphors of regality. To take one example, the adoption of the title shāh by spiritual guides coincided with the Būyids' (932-1062) assumption of the same title, according to Richard Gramlich and Fritz Meier before him, and highlights their efforts to delegitimate Shi'i Būyid rule. ${ }^{17}$ In the same period, the Ḥanafī Sufi Hakīm Abū al-Qāsim Samarqandī (d. 953), referred to Abū Hanīfa (d. 767), eponym of the Hanafī madhhab as the shāhanshāh of fiqh (jurisprudence) in his popular Sawād al-a'zam, and traced his lineage back

15 I have written elsewhere on the political valences of Nizām al-Mulk's alleged disdain for Shi' is and for non-Shāfi ìs in general, see Yavari, The Future of Iran's Past, 105-26; and Neguin Yavari, "Deciphering Difference in Premodern Islamic Political Thought," in Origin, Transmission and Metamorphosis of the Concept of Adab, ed. Catherine Mayeur Jaouen, Francesca Bellino, and Luca Patrizi (Leiden: Brill, forthcoming 2019).

16 For a concise overview of previous scholarship, see Luca Patrizi, "Adab al-mulūk: Lutilisation de la terminologie du pouvoir dans le soufisme médiéval," in Ethics and Spirituality in Islam: Sufi adab, ed. Francesco Chiabotti, Eve Feuillebois-Pierunek, Catherine Mayeur-Jaouen, and Luca Patrizi (Leiden: Brill, 2016); and for the far-reaching impact of the close ties between the Baghdad-based Sufi master 'Umar al-Suhrawardi (d. 632/1234) and the 'Abbāsid caliph al-Nāṣir, see Ohlander, Sufism in an Age of Transition, 187-248.

17 Richard Gramlich, Adab al-mulūk: Die Lebensweise der Könige (Stuttgart: Kommissionsverlag Steiner, 1993), 5-6 of Gramlich's "Introduction," as quoted in Patrizi, "Adab almulūk," 205-06; Fritz Meier, Zwei Abhandlungen ūber die Naqšbandiyya (Istanbul: In Kommission bei Franz Steiner Verlag, 1994), 188-95. 
to the pre-Islamic Sasanids (224-650). ${ }^{18}$ Jean-Claude Garcin ${ }^{19}$ and Alexandre Papas ${ }^{20}$ have studied Sufi strategies for appropriating power - symbolic and political - beginning in the $14^{\text {th }}$ century in the Maghrib and India, and in the $15^{\text {th }}$ century in Egypt. In a recent study, Luca Patrizi found similar analogies between political and spiritual power in much earlier texts, such as the $10^{\text {th }}$-century anonymous Kitāb Adab al-mulūk fì bayān haqāàiq al-tașawwuf, wherein the assumption of regality by Sufi masters is fully conceptualized as al-mulükiyya al-șüfiyya (Sufi kingship). ${ }^{21}$

Both the texture and the tenor of Sufi involvement in political life changed dramatically in the altered landscape of the Islamic world in the post-Mongol period, in the Maghrib, Egypt, Iran, Asia Minor, Central Asia, and India. ${ }^{22}$ The emergence of Sufi silsilas - or chains of authority that linked living leaders to the Prophet and entwined moral exemplars to create saintly genealogies in the Mongol and Tīmūrīd periods (ca. mid- $13^{\text {th }}$ to early $16^{\text {th }}$ centuries) is an important watershed in this regard. ${ }^{23}$ Genealogical tables and 'ilm al-rijāl as legitimacy tools have of course been a widespread feature since early times, most notably among hadith scholars and Turkic dynasts. With silsilas, Sufis forged a corporate identity, Devin DeWeese argues. ${ }^{24}$ In this new template, heirship was no longer a mere

18 Abū al-Qāsim Isḥāq b. Muhammad Ḥakīm Samarqandī, Tarjumah-i al-Sawād al-áżam, ed. 'Abd al-Hayy Habibi (Tehran: Bunyad Farhang Iran, 1969), 22. Incidentally, Khwāja Muhammad Pārsā revised Kitāb Sawād al-a'zam in 1393, to make the language more contemporary.

19 Jean-Claude Garçin, Espaces, pouvoirs et idéologies de l'Égypte médiévale (London: Variorum Reprints, 1987).

20 Alexandre Papas, Soufisme et politique entre Chine, Tibet et Turkestan: études sur les Khwajas Naqshbandis du Turkestan oriental (Paris: Jean Maisonneuve, 2005); and Alexandre Papas, "No Sufism without Sufi Order: Rethinking Tarīqa and Adab with Kāsānī Dahbidī (1461-1562)," Kyoto Bulletin of Islamic Area Studies 2, no. 1 (2008).

21 Luca Patrizi, "Adab al-mulūk: L'utilisation de la terminologie du pouvoir dans le soufisme médiéval," in Ethics and Spirituality in Islam: Sufi adab, ed. Francesco Chiabotti, Eve Feuillebois-Pierunek, Catherine Mayeur-Jaouen and Luca Patrizi (Leiden: Brill, 2016).

22 Lawrence G. Potter, "Sufis and Sultans in Post-Mongol Iran," Iranian Studies 27, no. 1/4 (1994): 77-82; and Jo-Ann Gross, “The Naqshbandīya and Khwāja 'Ubayd Allāh Aḥrār," in The Letters of Khwāja 'Ubayd Allāh Ahrrār and His Associates, 'Ubayd Allāh ibn Maḥmūd Ahrār, ed. Jo-Ann Gross and Asom Urunbaev (Leiden: Brill, 2004), 14-17. On the spread of institutional Sufism from Iran to the western Islamic domains, see Richard W. Bulliet, Islam: The View from the Edge (New York: Columbia University Press, 1993), 145-68.

23 Shahzad Bashir, Sufi Bodies: Religion and Society in Medieval Islam (New York: Columbia University Press, 2013), 11-12.

24 Devin DeWeese, "Spiritual Practice and Corporate Identity in Medieval Sufi Communities of Iran, Central Asia, and India: The Khalvatī/'Ishqī/Shaț̣ārī Continuum," in Religion and Identity in South Asia and Beyond: Essays in Honor of Patrick Olivelle, ed. Lindquist 
biological matter. Succession was determined by spiritual affinity and personal charisma rather than descent.

Among those to adopt the silsila model was the Naqshbandiyya community that sprouted from several Sufi lineages - collectively known as the Khwājagān - in the $14^{\text {th }}$ century, under the leadership of Bahā al-Dīn Naqshband (d. 1389) and his disciples. A century later, now led by 'Ubayd Allāh Aḥrār (d. 1490), the protagonist of Kāshifî̀s Rashaḥāt, the community spread throughout Central Asia and the Ottoman empire, including Syria and the Hijaz. Initially, inherited leadership and the silsila were both rejected among the Naqshbandīs,

leaving personal charisma (including direct spiritual contact with deceased masters or the Prophet himself) as the main grounds of leadership, even if, of course, shaykhs also could identify their immediate teachers and therefore could pose as their spiritual heirs. ${ }^{25}$

The adoption of the silsila model was instrumental in facilitating the spread of Naqshbandī influence; and that new identity was amplified in collected biographies such as Jāmīs Nafaḥāt al-uns and Rashaḥāt itself.

The silsila template was essentially a rhetorical strategy used to distinguish one Sufi order from another, as Alexandre Papas has suggested. ${ }^{26}$ His point draws attention to narrative strategies as a clue to understanding what Sufi communities did, and how they participated in and reshaped power relations in the Islamic world, and invites close reading and interpretation, suggesting that there is more to Sufi movements than theosophical debate. The interconnections between peers, disciples, mentors and exemplars were also integral to the institutionalization of Sufism, which was crafted primarily on the narrative plane. This is only superficially a paradox as I hope to explain below. Various Sufi groups bound their community to past authority through histories and genealogies so that doctrine and practice could be reinterpreted to accommodate and outlive changing circumstances, the true prize of institution-building.

Steven E. (London; New York; Delhi: Anthem Press, 2011), 251-54.

25 Jürgen Paul, "The Rise of the Khwajagan-Naqshbandi Sufi Order in Timurid Herat," in Afghanistan's Islam: From Conversion to the Taliban, ed. Nile Green (Oakland, California: University of California Press, 2017), 81. On Bahä' al-Dīn's explanation of why the silsila is not required, see Aḥmad Țāhirī 'Īrāqī, "Naqshī az Naqshbandiyān," in Jashn nāma-i Muhammad Parwīn Gunābādī, ed. Muhsin Abu al-Qasimi (Tehran: Tus, 1975), 267-74.

26 Alexandre Pappas, "Shaykh Succession in the Classical Naqshbandiyya: Spirituality, Heredity, and the Question of Body," Asian and African Studies 7, no. 1 (2007): 37. 
Sufis lineages in Iran and Central Asia were also key participants in the process of vernacular regionalization, to use Travis Zadeh's term, continuing a tradition that commenced earlier in the $10^{\text {th }}$ century under the auspices of the Ghaznavid (977-1186) and Sāmānid (819-1005) local dynasties, and was initially confined to producing Qur'an commentaries in Persian. ${ }^{27}$ The text studied here, Rashahăt 'ayn al-ḥayāt, enjoys the distinction of being the first dedicated collected biography of a single Sufi community - as opposed to earlier ones that charted and classified vitae of all Sufi luminaries, regardless of creedal orientation. It is also the fourth collected biography of Sufis written in Persian. ${ }^{28}$ Significantly, the adoption of Persian as the language of Sufism was a deliberate and even theoretical move by Sufi thinkers, as is evident in the discussion on the relative merits of Arabic and Persian in the Kubrawī master 'Alä' al-Dawla Simnānīss (d. 1336) "Zayn al-mu'taqad li zayn al-mu'taqid" to cite but one example. Noting that all languages are ill-suited for expressing abstract principles, Simnāni points to Persian's particular inadequacies when compared to Arabic, and relies on Arabic loanwords to instruct his disciples in their quest for the Truth (haqq, haqiqat). ${ }^{29}$

Lamenting the limitations of the Persian language was not limited to Sufi authors. Simnānī echoes the sentiments of the celebrated scholar and polymath Abū Rayhāān Bīrūnī (d. after 1050) on the inadequacies of Persian

27 Travis Zadeh and Alya Karame, "The Art of Translation: An Early Persian Commentary on the Qurān," Journal of Abbasid Studies 2 (2015): 185; and for a more comprehensive account of the emergence of New Persian literature, see Gilbert Lazard, "The Rise of the New Persian Language," in The Cambridge History of Iran, Volume 4, The Period from the Arab Invasion to the Saljūqs, ed. R. N. Frye (Cambridge: Cambridge University Press, 1975), 628-32.

28 Rashahāat follows after Abū al-Ḥasan 'Alī Hujwīrīs (d. 1073) Kashf al-mahjūu, Farīd al-Dīn 'Atțār's (d. 1221) Tadhkirat al-awliyä', and Jāmī’s Nafaḥāt al-uns. For a comparative analysis of Persian-language Sufism, see Denise Aigle, "Aț̣āar's Tadhkirat al-awliyā' and Jāmī’s Nafaḥāt al-uns: Two Visions of Sainthood," Oriente Moderno 96, no. 2 (2016).

29 Maria Giovanni Martini includes a critical edition of 'Alā al-Dawla Simnānī’s "Zayn almu'taqad li zayn al-mu'taqid," in his 'Alā al-Dawla al-Simnānī between Spiritual Authority and Political Power: A Persian Lord and Intellectual in the Heart of the İlkhānate (Leiden: Brill, 2017), 379. Appraisals of the relative merits of Arabic and Persian are not rare. See, for example, Jurfādiqānīs lament in his translation of al-'Utbīs (d. ca. 1036 or 1040) history of the Ghaznawids, completed in 1206-7, Abū al-Sharaf Nāṣiḥ b. Zafar Jurfādiqānī, Tarjumah-i Tārīkh-i Yamīnī, ed. Muhammad Ja'far Shíar (Tehran: Bungah Tarjumah va Nashr Kitab, 1978), 10. For more on the face-off between Arabic and Persian, see 'Alī b. Aḥmad Asadī Ṭūsī’s (d. 1072-3) account of a debate between an Arab and a Persian reproduced in Djalal Khaleghi-Motlagh, "Asadī Țūsī 2," Majallah-i Dānishkadah-i adabiyāt va 'ulūm-i insānī Danishgāh Firdawsì 14, no. 1 (1978). 
for writing scientific prose. Bīrūnī described the fate of a scientific text when translated into Persian as follows:

...it loses all clarity; its horizon becomes blurred and its practical application disappears. The function of the Persian language is to immortalize historical epics about the kings of bygone ages and to provide stories to tell on night-watches. ${ }^{30}$

By establishing Persian as the language of this new piety that is mindful of its audience, ${ }^{31}$ by downplaying sectarianism while at the same time upholding boundaries and marking communities (as we shall see), and by reconfiguring the principle of hereditary rule to combine charisma with the legitimacy of past authority, Sufi communities redefined the ideational landscape of late medieval/early modern Khurasan. How the Sufis drew on the past was a key component of that transformation, and in the case of the Naqshbandiyya, spiritual authority was twined with the remembrance of al-Fārmadhi $\overline{1}^{32}$ who is credited in Rashahāt 'ayn al-hayāt as a principal fount of the Naqshbandiyya. The Naqshbandīs also recast the Sunni-Shi'i divide, a constitutive element of the new piety they advocated. What follows is a detailed investigation of the illocutionary force of the text. I argue that the text's apparent identity as a genealogy is in fact the top layer of a complex edifice, designed to serve as a new template of authority; one that in effect proselytized a nation.

30 Abū Rayhān Bīrūnī, Al-Ṣaydana, as cited in Lazard, "The Rise of the New Persian Language," 631.

31 The bibliography on this subject is extensive. For a recent example, see Jāmì in Regional Contexts; The Reception of 'Abd al-Raḥmān Jämī's Works in the Islamicate World, ca. $9^{\text {th }} / 15^{\text {th }}-14^{\text {th }} / 20^{\text {th }}$ Century, Thibaut d'Hubert and Alexandre Papas, eds. (Leiden: Brill, 2018), 27-223.

32 The present study does not engage with doctrinal specificities, but it is useful to bear in mind that certain elements of the teachings of al-Fārmadhīs star pupil al-Ghazzālī were incorporated into Khwājagān-Naqshbandī principles according to Alexei Khismatulin, including Ghujduwānīs eight principles that shaped the Khwājagān. Khismatulin's point is that rather than a Persian translation of his Iḥya 'ulūm al-dīn, al-Ghazzālìs Kìmìyā-yi $s a^{\prime} \bar{a}$ dat must be considered as an independent text and one of the earliest specimens of Sufi books written in Persian; see Alexei A. Khismatulin, “'The Alchemy of Happiness': Al-Ghazālīs Kìmìyā and the Origins of the Khwājagān-Naqshbandiyya Principles," in Ideas, Images, and Methods of Portrayal, ed. Sebastian Günther (Leiden: Brill, 2015). 


\section{Forging a Context of One's Own}

Kāshifî̀s Rashahạt 'ayn al-ḥayāt is a clear example of textual institutionalization. ${ }^{33}$ The author hailed from a family of scholars active at the court of the last Tìmūrid sultan Husayn Bāyqara who ruled in Herat from 1469 to 1506. His famous father, the preacher and polymath Husayn Wā'iz al-Kāshifī (d. 1504), wrote on both Sunni and Shi'i topics. ${ }^{34}$ His exegesis on the Qurān was popular among Persian speakers in eastern Iran and northern India (the vast majority of whom were Sunni); while prominent philo-'Alīd themes and references in the family's writings generated accusations of Shi'i sympathy. ${ }^{35}$

Both Kāshifīs were prominent members of the Naqshbandī community, a Sunni Sufi community that rejected antinomian currents and sought to integrate the Sufi tariqa (spiritual path, almost Tao) with the practice of the shari ${ }^{-} a{ }^{36}$ Such was their steadfast orthodoxy that one $13^{\text {th }}$-century Naqshbandī leader boasted that only one of his disciples would have sufficed to save al-Hallāj who was accused of heresy and executed by the Abbasid caliph in 922, and set him on the correct mystical path. ${ }^{37}$

A collected biography with a distinctive authorial voice rather than a descriptive primer on Sufi etiquette, the approach to Sufi history in Rashahāt is thoroughly classificatory with a prescriptive spatial structure.

33 For an insightful discussion of the codification and institutionalization of Sufi thought and practice in Baghdad, see Ohlander, Sufism in an Age of Transition, 187-248.

34 For his biography, see Maria E. Subtelny, “Kāšefi, Kamāl-al-Din-Ḥosayn, Wāeẓ̣," Encyclopaedia Iranica Online, accessed June 4, 2019. Originally published December 15, 2011. http://www.iranicaonline.org/articles/kasefi_kamal. According to Aḥmad Ṭāhirī 'Irāqī, Ḥusayn Kāshifī followed the Ḥanafì madhhab, see his "Introduction," in Khwāja Muhammad Pārsā-yi Bukhārāīì, Qudsiyya, ed. Aḥmad Ṭāhirī 'Irāqī (Tehran: Tahuri, 1975), 27.

35 Abbas Amanat, "Meadow of the Martyrs: Kāshifïs Persianization of the Shi'i Martyrdom Narrative in the Later Tīmūrid Herat," in Culture and Memory in Medieval Islam: Essays in Honour of Wilferd Madelung, ed. Farhad Daftary and Josef W. Meri (London: I. B. Tauris, 2003); and Mu'iniyan claims that Fakhr al-Dīn Șafì 'Alī may have converted to Shi' ism sometime in the early decades of the $10^{\text {th }} / 16^{\text {th }}$ century; see Rashahät, "Introduction," 85-86.

36 For more on the Naqshbandiyya and a comprehensive account of the extensive secondary literature on their history and creed, see Jürgen Paul, "The Rise of the Khwājagān-Naqshbandiyya Sufi Order;" Dina Le Gall, A Culture of Sufism: Naqshbandis in the Ottoman World, 1450-1700 (Albany: State University of New York Press, 2005), 14-33, and Jo-Ann Gross, "The Naqshbandīya and Khwāja 'Ubayd Allāh Aḥrār," 1-22.

37 Rashahāat, I, 66. 


\section{In Kāshifî̀s own words:}

The construction of this collection rests on a preamble (maqäla) that recounts the Khwājagān generations of the Naqshbandī silsila, three chapters (maqșad) - each divided into three sections ( fas l $)$ - on the life and accomplishments of Khwāja 'Ubayd Allah Ahrār, his origins and the beginnings of his quest; firsthand accounts of his doctrines, beliefs and the anecdotes he has recited; and mirabilia attributed to him; followed by an epilogue (khätima). ${ }^{38}$

Kāshifîss organizational principle is decidedly teleological: it begins with a long introduction on the birth of the Naqshbandi silsila, culminates in the life and legacy of Ahrār the Sufi master who wielded enormous political influence, and ends with his transition from this world to the next, and the brief tenure of two of his sons as spiritual authorities. This fortuitously coincides with the downfall of the Tìmūrids in 1501, and the fall of Samarqand to the Uzbek Shībānī Khan (r. 1501-10). In Kāshifî̀s own words, the text is constructed in this manner because "from Him is the beginning and to Him the return." ${ }^{39}$

The preamble - the longest section of the book - crafts a prehistory for the Naqshbandīs by linking them to the earlier Khwājagān order, with the $12^{\text {th }}$-century Khwāja Yūsuf Hamadānī (d. 1140) as its founder. Yet the origins of the Khwājagān-Naqshbandī lineage are stretched further back to the lifetime of Abū Bakr al-Șiddīq (d. 634), the first caliph who ruled for two years following the death of Muhammad in 632. ${ }^{40}$

Apart from the connection to the first caliph, the preamble also includes a complex genealogy that connects the order via several distinct lineages to Abū Bakr's main rival, 'Alī b. Abī Ṭālib (d. 661), Muhammad's cousin and son-in-law, and to his progeny, who in due course came to be regarded as the twelve holy imams of the Shi'is. Khwāja Yūsuf Hamadānī appointed

38 Rashậāt, I, 10.

39 Rashahāt, I; the phrase is a frequent Qur'anic quote [Q 2:156].

40 Conflating genealogies was de rigeur in Tīmūrid Herat. Tīmūr (Tamerlane, r. 1370-1405) himself claimed, apart from the title șạhib qirān (Lord of the Auspicious Conjunction), genealogical affiliation with Chingis Khan (r. 1206-27), and 'Alī, the aforementioned cousin, son-in-law and eventually successor of Muhammad. For Tīmūr's colorful genealogy, see John E. Woods, "Tīmūr's Genealogy," in Intellectual Studies on Islam: Essays Written in Honor of Martin B. Dickson, ed. Michel M. Mazzaoui and Vera B. Moreen (Salt Lake City, UT: University of Utah Press, 1990); Beatrice Forbes Manz, "Tamerlane and the Symbolism of Sovereignty," Iranian Studies 21, no. 1-2 (1988); and Denise Aigle, "The Transformation of a Myth of Origins, Genghis Khan and Timur," chap. 6 in The Mongol Empire Between Myth and Realities, Historic Anthropological Studies (Leiden: Brill, 2014). 
four caliphs to represent him and to propagate his teachings. That too, is an appropriation of the past, as it resonates with the four rightly guided caliphs who ruled the Islamic community following Muhammad's death (Abū Bakr, r. 632-34, 'Umar b. al-Khațțāb, r. 634-44, 'Uthmān b. 'Affān, r. 644-56, 'Alī b. Abī Țālib, r. 656-61). That template of pious government wherein succession was not hereditary lasted for thirty years, after which dynastic rule prevailed when the Umayyad dynasty was founded in 661. It deserves mention here that statecraft organized around the principle of four, as in the fourfold division of the Mongol empire following Chingis' death in 1227, or the four subordinate beys leading four ruling tribes, often referred to as clans in modern scholarship, prevailed in the Mongol successor states and was a staple of Turco-Mongol political life. ${ }^{41}$

The fourth of Hamadānī's caliphs was 'Abd al-Khāliq al-Ghujduwānī (d. 1220). Among those who mentored his mentors was the Prophet's great great grandson and Shi'i imam Ja'far al-Ṣādiq who had passed in 765, a long time before Ghujduwānī’s teachers were born. Ja'far al-Ṣādiq was a great grandson of 'Alī b. Abī Ṭālib and a descendant on his mother's side of Abū Bakr. ${ }^{42}$ In other words, he was scion of the two leading contenders for Muhammad's mantle which in time became known as the Sunni and Shi'i communities, where Shi'ism is best considered as a conceptual antipode to Sunnism, rather than a derivative of it. The fusion of Sunni and Shi'i lineages of authority is a recurring feature of Naqshbandī creed, as we shall explore in further detail below.

The lineages, genealogies and biographical information in the text are accompanied by detailed discussions of rashahāt (sprinklings, singular rashḥa), teachings transmitted by the masters. ${ }^{43}$ In fact, Rashahăt 'ayn al-hayāt is a quasi three-dimensional text, one where a genealogy is mapped spatially and is best read with the aid of a floorplan rather than a table of contents. In this spatial classification, each tabaqa (generation as well as floor) is

41 Uli Schamiloglu, "Tribal Politics and Social Organization in the Golden Horde," Unpublished PhD Dissertation, Department of History, Columbia University, 1986, 19-32, 127-71. For a parallel system of four spiritual leaders alongside the four qarači beys, see 71-73; for the four uluş emirs in İlkhānid Iran (1256-1335), 83-86.

42 Abū Bakr's grandson Qāsim was Jáfar al-Ṣādiq’s maternal grandfather, see Rashaḥāt, I, 11-13.

43 Rashahăt, I, 38-51; the dicta proffered by Naqshbandī masters also functioned to cool one's spirit, as in the sprinklers used in summer houses, another meaning associated with rashḥa/rashahàt. 
built upon a set of four pillars, the caliphs appointed by the previous master shaykh. While the Sufi masters uphold the floors, the walls of the edifice are provided by rashahāt or sprinklings, rules and instructions that flow from generation to generation to bind and nurture the Naqshbandī community. The text traces each set of four lineages, each of which in turn produce their own successor chains, so as to draw an ever-expanding cladogram comprising successive generations as they replicate themselves fourfold.

The house that the Naqshbandīs build, or at least the one that Kāshifī builds for them, boasts both concrete pillars and abstract ones. While prominent masters or lead chains, their caliphs and their sprinklings represent the former, the collusion of 'Alī and Abū Bakr in the forged prehistory that brought about the order in the earliest days of Islam is an example of an abstract pillar. As mentioned, the template of authority in Rashahāt is explicit in its intention to connect Naqshbandī-Khwājagān elders with both Sunni and Shi'i luminaries. 'Alīd exemplars are aplenty, as is explicitly anti-Shi'i polemic. In a master stroke, Kāshifï both historicizes creeds and ideologies by reducing them to human actors, a strategic move necessary to instrumentalize the past for present concerns; and, at the same time, defies natural law by crafting an anachronistic genealogy that assigns $7^{\text {th }}$-century teachers and companions to $12^{\text {th }}$-century Sufi masters. The multiple connections and inter-connections between the various lead chains, their teachers - actual and imagined - and their successors, prevent a chronological reading of the history of the Naqshbandī order. Kāshifīs genealogy does not trace the development of his Sufi community over time, but instead conjures up a history of the past that underscores themes, tropes and watersheds that bolster its creedal and political standing by forging its own ideational context.

And he does more still. For the house that Kāshifì builds is part of a country - a land that the Naqshbandīs come to claim as their own. It is enclosed by Samarqand, Herat, and Bukhara on one side, and stretches widely, through travel and diffusion, as well as lineage, to include Baghdad, Egypt/Syria, the Hijaz, and India. Hamadānī traveled to Baghdad at the age of eighteen, and studied in Isfahan and Bukhara, and had followers in Iraq, Khurasan, Khwarazm and Transoxiana. ${ }^{44}$ And Khwāja Bahā’ al-Dīn Naqshband's exertions took him around Khurasan, Central Asia, Hijaz and

44 Rashahāt, I, 13-14. 
Syria. ${ }^{45}$ In fact, the Naqshbandīs had several centers: the community was prominent in the region of Bukhara during the lifetime of Naqshband, the disciples around Jāmī were anchored in Herat, and Aḥrār and his devotees moved to Samarqand in the mid- $15^{\text {th }}$ century. Armando Salvatore has written on the conceptual ties between locality and institution-building in modern Sufi organizations. ${ }^{46}$ Beyond holy sites, however, which is the focus of Salvatore's piece, the house that Kāshifì built also reveals the territorial claims of the Naqshbandīs. By affixing a place for Sufi activity not just in terms of a school, or a place of congregation, a hostel, or even a sacred site associated with a specific master - the traditional geographies of Sufi piety - but also in terms of a country, Kāshifī set about the task of institutionbuilding. In traveling saints, in acquisitions through conquest by princes under Sufi protection, and most importantly in links forged across time and space, or to borrow Yuri M. Lotman's term, a semiosphere, ${ }^{47}$ a cultural boundary crafted by proselytization, Kāshifī and his Naqshbandī friends redrew the contours of the landscape of politics and of religion in late medieval Islam, and claimed land to transform their spiritual community into a concrete, if textual, institution.

\section{Contextualizing Old Divides in the New Piety}

The desired outcome of Kāshifīs constructivist agenda is a model for religion which can be put to use in politics - a religious blueprint for a genuinely Islamic society that tempers religious fervor with the preservation of public peace, while simultaneously drawing on the past to legitimate the direct involvement of religious leaders in political life. Kāshifî̀s template (much like Khomeini's several centuries later) is for a public religion, ${ }^{48}$ one

45 Rashahät, I, 93-99.

46 Armando Salvatore, "Notes on Locality, Connectedness, and Saintliness," in Dimensions of Locality: Muslim Saints, their Place and Space, Yearbook of the Sociology of Islam 8, ed. Georg Stauth and Samuli Schielke (Bielefeld: transcript Verlag, 2008). See too Martha L. Henderson. "What is Spiritual Geography?" Geographical Review 83, no. 4 (1993).

47 Yuri M. Lotman, Universe of the Mind: A Semiotic Theory of Culture (Bloomington: Indiana University Press, 1990), 123-42.

48 By public religion I have in mind a concept similar to what the "Early Modern Civil Religion Reading Group" based at Newcastle University have chosen to call "civil religion" - a language and concept seeking to reconcile government with religion, and to craft a model for religion that is conducive to maintaining public peace. "Liberated from the confines 
that lubricates the machinery of governance. This illuminates the rising fortune of Sufi movements in the $11^{\text {th }}$ century, as part of a concerted effort by politicians and religious leaders to stem confessional strife, and address a political crisis that had been simmering for decades.

As mentioned, institutionalized Sufis movements came of age a century or so after Nizām al-Mulk's death, in the course of the two and a half centuries that separate the fall of the Abbasids in 1258 and the coming to power of the Șafavid (1501-1736) ruling house. These are arguably the most critical centuries in the social and religious history of Iran, at the end of which an overwhelmingly Sunni Iran was transformed into a robustly Shi'i nation, or so at least the conventional story goes. The role of Sufi communities in transitioning Iran between the two creeds remains hotly debated. Hamid Algar attributes the rapid Shi'ification of Iran to a crypto-Shi' ism arising in Khurasan and moving westwards sometime after the $15^{\text {th }}$ century. Patricia Crone and others, including Abbas Amanat, see an increased devotion to 'Alī b. Abī Ṭālib and his progeny among Sunni Iranian Sufis in the $14^{\text {th }}$ and $15^{\text {th }}$ centuries that predisposed Sunnis in Iran to embrace Shi ism. ${ }^{49}$ The consensus in the field, though perhaps never explicitly recognized, is that states and governments were not the main agents of the social changes that overtook the Iranian/Persephone world from the $13^{\text {th }}$ to the $16^{\text {th }}$ centuries. Should that role instead be attributed to the Sufis?

It is in this light that the anti-Shi'i polemic of the Naqshbandis is best understood. While they accept the sanctity and special status of 'Ali and his progeny, and even the hotly contested concept of a mahdi that will return at the end of time, the venom of Naqshbandi Sufis is directed at the rejectionist strand that has shaped Shi'i history from its very inception. Shi' $i$ failure to accept the choice of the majority of the Muslim community upon Muhammad's death, and the ensuing split that has defined Islamic thought and history ever since, is regarded as an unpardonable offence.

of being a subsidiary to republicanism," and explored as an intellectual tradition on its own terms, they argue, civil religion emerges as a "rich and complex discourse, through which efforts were made to develop a persuasive vision for a religion conducive to a tolerant and harmonious citizen body," see https://newcastlecivilreligion.wordpress.com/ category/news/, accessed June 27, 2019.

49 For a summary of the debate, see Hamid Algar's review of Patricia Crone, The Nativist Prophets of Early Islamic Iran: Rural Revolt and Local Zoroastrianism, in Journal of Shi'a Islamic Studies 8, no. 3 (2015); and Christoph Werner, "Die Schia in Iran: Von der Minderheit zur Mehrheit," in Religiöse Minderheiten und gesellschaftlicher Wandel, ed. Edith Franke (Wiesbaden: Harrassowitz, 2014). 
Hence the appellation râfiḍi (rejectionist, referring to those who rejected the consensus of the majority of the Muslim community) in Naqshbandi and other polemical literature. ${ }^{50}$ In that vein, the Sufis of this period present their creed not as a hybrid Sunni-Shi'i affair, or even a synthesis of the two, but instead as a new religion, albeit cast as "the true Sunni" creed. In the words of Simnānī:

true Islam is that of the Sunnis, the most balanced of persuasions, in which the four rightly guided caliphs and Muhammad's progeny (ahl al-bayt) and his disciples are praised; no Muslim is accused of disbelief; and all prophets, scriptures and angels are respected, so that confessional prejudice is eschewed and various communities can live in peace. ${ }^{51}$

In this novel iteration of the Sunni creed, Sufis are its most perfect practitioners, as we shall explore in more detail below.

A similar architecture of the Sufi creed, again found in the company of a new template of public Islam, is the central thesis of Simnānìs Al-Wärid al-shārid al-țārid shubhat al-mārid, ${ }^{52}$ a refutation of philosophy, specifically of Avicenna (d. 1037) and the Aristotelian tradition. Al-Wärid is composed of three architectural stages, argues Giovanni Maria Martini. It demolishes an old construction that was built with the 'wrong' architecture, it uses pieces from the old edifice to reconstruct the 'right' new architecture, and finally, it rebuilds a new edifice. First, a demolition ball is taken to philosophical views, then Simnāni collects viewpoints on those views from across the spectrum of Islamic thought, and shows how all except one are incompatible with the rest. To rebuild the edifice correctly, he ranks the various creeds

50 The succession crisis that followed Muhammad's death in 632 divided the nascent Islamic community. The shî́at 'Alī (followers of 'Alī), Shi'a for short, held that 'Alī had been robbed of his rightful position as the Prophet's heir and leader of his community. The opposing view, which was the default position of the vast majority of Muslims, came to be known in time as the ahl al-sunna wa al jamāa (those who uphold past precedence and the community's consensus), Sunni for short. The latter argued that as judgment belongs to God alone, Muslims should postpone taking a stance on the issue of succession. In the Sufi writings considered in this study, the Shi' is are scorned not on account of minutiae of doctrine, but because they rejected the consensus of the community, refused to accept the course of history and sowed dissent.

51 'Alä' al-Dawla al-Simnānī, "Zayn al-mu'taqad," in Martini, 'Alä' al-Dawla al-Simnānī between Spiritual Authority and Political Power, 298-9.

52 It is telling that Simnānī also practiced silent dhikr, and corresponded with the Naqshbandī Khwāja 'Alī Rāmtīnī on that topic. See Jamal J. Elias, The Throne Carrier of God: The Life and Thought of 'Alä' ad-dawla al-Simnānì (Albany: State University of New York Press, 1995), 201; and Rashahāat, I, 63. 
from the most exclusionary to the most universal. The most limited view belongs to the naturalists, followed by the physicists/mathematicians, the philosophers, and finally the Sufis, who sit atop the entire edifice, as a roof..$^{53}$ Its practice is the purest, its outlook the most universal, and its worship the most perfect. ${ }^{54}$ Just as the Sunni creed, the wider net, is the most universal of Islam's creeds, the Sufi madhhab, the fifth Sunni madhhab, is the most universal: it is built upon the principle of community and consensus. ${ }^{55}$ It comprises all that is esoteric and material; it honors all proper boundaries, desists from slander and raising accusations of heresy and infidelity against anyone who prays to the Ka'ba, and its followers revere their religious leaders, the Prophet's companions and his family, and all prophets and messengers. ${ }^{56}$ Simnānīs ideal creed is not the antidote to Shi'i doctrine, but the optimal safeguard against factional zeal and sectarian violence. It does not seek to reconcile Shi'i beliefs with Sunni ones but to construct a new path to true Islam, the Truth.

An unsectarian worldview cloaked in sectarian terminology is the hallmark of Naqshbandī langue. They considered the Shāfi'î al-Fārmadhī among their principal founders, but many of their leaders, including Khwāja Muhammad Pārsā and Jāmīi, ${ }^{57}$ are known to have hailed from a Ḥanafī background. Khwāja Yūsuf Hamadānī is claimed for the Ḥanafīs in Rashahāt, but he is listed as a Shāfi î in several earlier sources. ${ }^{58} \mathrm{Al}-$ though Kāshifī notes 'Ubayd Allāh Aḥrār's veneration for the Imam Abū Hanīfa, frequently referred to as imam-i a'zam (supreme leader), such high esteem has its limits. In one anecdote, the Sufi master Zayn al-Dīn Abū Bakr Tāybādī (d. 1389) asks one of his disciples if he likes the Imam-i A'żam Abū Hanifa more than his own shaykh. The disciple confesses that he likes his own master better. Offended at his response, Zayn al-Dīn insults the man and expels him from the gathering. Moments later, he

53 Martini, 'Alä' al-Dawla al-Simnānī between Spiritual Authority and Political Power, 126-28.

54 Martini, 211.

55 Martini, 111-12, 216.

56 Martini, 211-12, 455.

57 Dina Le Gall suggests most Naqshbandīs, at least among those in the east, were of the Hanafi persuasion, whereas among their adherents in the Kurdish territories, Arabia and Egypt, Shāfí ism prevailed; see A Culture of Sufism, 92-93; and according to Algar, Jāmī at least "does not appear to have attached any significance to this fact," Algar, Jami, 129.

58 Al-Samānī's $12^{\text {th }}$-century collected biography of Shāfi'ī notables is one such example, see Wilferd Madelung, "Yūsuf al-Hamadānī and the Naqšbandiyya," Quaderni di Studi Arabi 5, no. 6 (1987-1988), 499-509. 
regrets his extreme reaction and seeks the disciple in order to apologize. The disciple says,

I followed the madhhab of the Imam-i A'zam for several years, but none of my defects were rectified. After a few days following this leader, however, I have shunned all dishonor. What is wrong with liking such a master more than the Imam-i A'zam, and is it written anywhere that such sentiment is abhorrent and forbidden?

Zayn al-Dīn apologizes and praises him. ${ }^{59}$ The moral of the story, it appears, refutes the significance of madhhab affiliation. Finally, from a poem valorizing the Sufi path, we learn that the truth of divine love is revealed only to those with an esoteric inclination and not to jurists; Abū Ḥanīfa did not teach it, and al-Shāfi î̀ (d. 820) said nothing on the matter. ${ }^{60}$

While Naqshbandī commitment to orthodoxy and to the Sunni consensus is ubiquitous, the political freight of their allegedly anti-Shi'i stance remains contested. Consider an anecdote by 'Ubayd Allāh Ahrār regarding the cursing of Abū Bakr by Shi'is: A Sufi master happened onto räfị̂̄ territory. A group of extremists gathered around his retinue and cursed Abū Bakr. The shaykh's companions wanted to attack the offenders. But the shaykh intervened:

Do not harm them, for they do not curse our Abū Bakr. Our Abū Bakr is different from their Abū Bakr. Their imagined Abū Bakr landed the caliphate without merit and bore ill-will against the Prophet and his family; we too repudiate their Abū Bakr.

The rejectionists (rāwäfid) regretted their actions and repented of their false beliefs. ${ }^{61}$ The account carefully segregates individual Shi' is from unpalatable dogma, but it also highlights the contingencies that divided the Muslim community, thus opening a path to reconciliation. The divergent readings of early Islamic history naturalize difference, and temper sectarian sentiment by suggesting a modus vivendi between conflicting creeds. They also stand in stark contrast to the violent and even obscene confrontations of the time between Shi'is and Sunnis as reflected in popular literature.

Dogma, even if well entrenched, is subject to interpretation. In one rashḥa, Aḥrār, drawing on the authority of two prominent Naqshbandī masters, suggests that a dedicated and careful disciple is not obligated to

59 Rashahāt, II, 462-63.

60 Rashahāt, II, 511.

61 Rashaḥāt, II, 490-91. 
follow a master to achieve spiritual perfection. Revelation makes it clear, he claims, that the holy book and prophetic precedence suffice as guidance. ${ }^{62}$

Nuance is key in distinguishing the proper from the deficient. The good and the proper in the Shi' $i$ worldview is carefully separated from its deficiencies with a command exhorting the true Sufi to hold descendants of 'Ali in the highest esteem, as laid out in a rashḥa. ${ }^{63}$ In his own writings, Khwāja Muhammad Pārsā (d. 1420), Bahä al-Dīn Naqshband's khalîfa active in Bukhara is equivocal in his full confidence in the probity of Muhammad's companions, a sui generis pillar of the Sunni creed, and in the necessity of venerating the twelve imams, a core element of the Shi'i school. ${ }^{64}$ The same has been said of Jāmī. Pointing to his writings on 'Ali and other Shi'i imams, Sajjad Rizvi suggests that Jāmīs triumphalist Sunni identity must be considered as part of a concerted effort to bolster Tīmūrid legitimacy against rival claims forwarded by Shi'i and messianic movements "through acts of appropriating for the Sunni imperial traditions the very figures and symbols that defined Shi' $i$ identity: the Imams." ${ }^{35}$

In another rashḥa, Ahrār is found to fix a Sufi cosmological hierarchy:

There is sharíat, țarīqat (Sufi path) and haqiqqat (truth): sharīat is fulfilling God's exoteric commands, tariqat is mindfulness and undivided attention to various aspects of the internal life, and haqiqat is sharp insight into those matters. ${ }^{66}$

The triangulated rules of piety in Ahrār's model abrogate any competition between sharía and tariqa by proposing a third plane that encompasses and transcends - in its purview as well as its content - the exigencies of both. Like Simnānī's philo-'Alid Sufi madhhab that integrates the teachings of the four Sunni schools of law with basic elements of the Shi'i creed, and surpasses them all, the reach of Ahrār's haqiqqa extends far beyond the ideals promulgated by both the sharía and the tariqa.

62 Rashahāt, II, 467.

63 Rashahāt, II.

64 Khwāja Muhammad Pārsā, Faṣl al-Khițāb (Tashkent: Litografiya Gulam Khasandzhanova, 1913), 400-43, as quoted in Hamid Algar, "The Naqshbandis and Safavids: A Contribution to the Religious History of Iran and Her Neighbors," in Safavid Iran and her Neighbors, ed. Michel Mazzaoui (Salt Lake City: University of Utah Press, 2003), 31. Khwāja Muhammad Pārsā is also known for updating the Sufi Abū al-Qāsim Isḥāq Samarqandīs Sawād al-a'zam, a popular exposition of the Hanafĩ creed; see Wilferd Madelung, "Abu'l-Qāsem Esḥāq Samarqandi," Encyclopaedia Iranica Online, accessed June 4, 2019. Originally published December 15, 1983. http://www.iranicaonline.org/articles/abul-qasem-eshaq.

65 Sajjad Rizvi, "Before the Safavid-Ottoman Conflict: Jāmī and Sectarianism in Timurid Iran and Iraq," in Jāmī in Regional Contexts, 255.

66 Rashahāt, II, 503. 
Resorting to a sectarian past is another feature of Naqshbandi history that is called upon to evidence its divisive core. The outlier Naqshbandi choice of performing dhikr, which, as noted above, also distinguished Abū 'Alī al-Fārmadhī from his peers, is one such example. Where the majority of Sufis practiced vocal dhikr, the Naqshbandis opted for the silent mode. In Naqshbandī lore, it was the prophet Khị̂r who initiated Ghujduwānī into the Sufi path, and gave him special dispensation to persist in silent $d h i k r .{ }^{67}$ In so doing, Ghujduwānī contravened the practice of Khwāja Yūsuf Hamadānī, who introduced him to the Khwājagān community. ${ }^{68}$ Ghujduwānīs prescription for silent dhikr was adopted by Baha' al-Din Muhammad Naqshband. When still the Khwājagān, the order practiced silent $d h i k r$ in private sessions and resorted to vocal incantation in public. The conversion from private silent $d h i k r$ and public vocal dhikr to silent dhikr to the exclusion of vocal incantation marked the revival of true piety in this Sufi community, and was commemorated by its being renamed the Naqshbandiyya. The rebranding must date to the $16^{\text {th }}$ century, 'Alī Asghar Mu'iniyan suggests, since Khwājagān still predominates in Jāmī’s Nafaḥāt and Kāshifî̀s Rashaḥāt. ${ }^{69}$ And Devin DeWeese and Jürgen Paul have shown that the connection was wrought at the expense of those collateral lines of the Khwājagān that did not lead to Bahā’ al-Dīn Muhammad Naqshband, and reflected internal disputes. ${ }^{70}$

67 Rashahāt, I, 35; Anna Krasnowolska, “Keżr,” Encyclopaedia Iranica Online, accessed June 4, 2019. Originally published April 15, 2009. http://www.iranicaonline.org/articles/ kezr-prophet.; Patrick Franke has gathered over a hundred accounts of encounters with Khidr, see his Begegnung mit Khidr: Quellenstudien zum Imaginären im traditionellen Islam (Stuttgart: Steiner, 2000); and for a superb description of Khidrr in Sufi literature, see Armando Salvatore, "Notes on Locality, Connectedness, and Saintliness".

68 According to Ghujduwānī’s Maqāmāt Yūsuf Hamadānī, Khwāja Yūsuf Hamadānī too practiced silent dhikr, although the claim is contradicted in Kāshifīs Rashahät, see Hamid Algar, "Abū Ya'qūb Yūsuf b. Ayyūb Hamadānī", Encyclopaedia Iranica Online, accessed June 4, 2019. Originally published December 15, 1983. http://www.iranicaonline. org/articles/abu-yaqub-hamadani.

69 See Mu'īniyān's "Introduction," Rashaḥāt, I, 45.

70 Devin DeWeese, "The Legitimation of Bahä al-Dīn Naqshband," Asiatische Studien 50, no. 2 (2006); and Jürgen Paul, Doctrine and Organization: The Khwājagān/Naqshbandìya in the First Generation after Bahäuddīn (Berlin: Das Arabische Buch, 1998), 18-30. Hamid Algar offers an alternative interpretation, see his review of Dina Le Gall's A Culture of Sufism: Naqshbandis in the Ottoman World, 1450-1750 in Journal of Islamic Studies 18, no. 3 (2007). 
The ideological freight of vocal vs. silent $d h i k r$ has, in addition, a sectarian component, according to Algar, who points to the association of vocal dhikr with 'Alī, and of silent dhikr with Abū Bakr. In Naqshbandī writings, the origin of silent dhikr dates to the Prophet's migration from Mecca to Medina. Fleeing persecution, Muhammad took refuge with Abū Bakr in a cave. The Quranic revelation:

[h] had no more than one companion; the two were in the cave, and he said to his companion, 'Fear not, for God is with us;' then God sent down His peace upon him [Q: 9:40];1

is read in that tradition to mark the birth of silent dhikr that provides the same peace that Abū Bakr received. ${ }^{72}$ The attribution of silent dhikr to Abū Bakr, however, must be understood as a later hagiographical interpolation, and certainly not indicative of standard Naqshbandi practice. The adoption of silent dhikr by Bahä' al-Dīn Naqshband followed intense inter-Naqshbandī strife, as documented in earlier sources, including the $14^{\text {th }}$-century Masālik al-'ârifìn. In the period before Bahä' al-Dīn, when neither uniform doctrine nor practice prevailed among the Khwājagān, both styles of dhikr were present, and both persisted among his followers. Khwāja Muhammad Pārsā, for example, advises those among his followers who engage in vocal dhikr to make sure that their heart is in sync with their tongue when so doing, which is necessarily a dispensation to persist in their practice. ${ }^{73}$ Nevertheless, there is no doubt that silent $d h i k r$ was the modus operandi of a good majority of Naqshbandi Sufis. What is questionable is whether that preference was endowed with a confessional lineage.

71 'Abdullah Ysuf 'Ali, The Meaning of the Glorious Quran, accessed June 4, 2019, http:// www.islam101.com/quran/yusufAli/QURAN/9.htm.

72 Hamid Algar, "Silent and Vocal dhikr in the Naqshbandī Order," in Akten des VII. Kongresses für Arabistik und Islamwissenschaft, Göttingen, 15.-22. August 1974, ed. Albert Dietrich (Göttingen: Vandenhoeck \& Ruprecht, 1976), 41; and Paul, Doctrine and Organization, $18-30$.

73 Muhammad Pārsā’s "Kashfiyya," still in manuscript, is cited in Paul, Doctrine and Organization, 28. 


\section{The adab of siyāsa in the New Piety}

The adab of siyāsa - the ethics of politics - is spelt out nicely in one anecdote, where the protagonist Ahrār explains how it is that the Naqshbandīs have not overcome their competitors. Had we not been preoccupied by the command to protect Muslims from injustice, Aḥrār claims,

there would not have been a single shaykh from another Sufi lineage who could boast even one disciple. But we need to interact with sultans to conquer their souls and in this manner avail the wellbeing of Muslims. ${ }^{74}$

Activism and involvement in the social world while continuing to tend to one's spiritual needs is explicitly endorsed in Naqshbandī teaching, as reflected in a series of paired contraries: khalwat dar anjuman, or seek solitude in the crowd, and safar dar wațan, or journey in the homeland (one's own soul), which point out that preserving one's spiritual equanimity is possible even if one goes into the crowd or attends a princely court, as long as one does not lose sight of a higher spiritual realm.

For spiritual leaders who claimed to shun mundane affairs, Sufi masters placed a heavy premium on proximity to power. That conundrum is nicely captured in a modern collected biography of Naqshbandi shaykhs by the Egyptian Sufi master and poet Yāsīn b. Ibrāhīm al-Sanhūtī (d. 1935). The Sufi worldview, he holds, is one that rests on shunning worldliness, but at the same time it is tasked with upholding justice, ensuring that governors act in accordance with the law of God, and promoting public welfare. ${ }^{75}$

That concept of a public religion that acknowledges the imperative of governance - as has been sketched in this study - exemplifies secularity, understood not in contradistinction to religion or at least not allied with or hostile to any particular religion, but rather in a more specific sense to denote those "institutionally as well as symbolically embedded forms and arrangements that distinguish between religion and other societal areas." ${ }^{\text {76 }}$

74 Rashahàt, II, 531.

75 Yāsīn b. Ibrāhīm Al-Sanhūtī, Al-Anwār al-qudsiyyah fì manāqib al-sādah al-Naqshbandiyya, (Cairo: Matbaáa al-Saáada, 1925), 130. For modern Naqshbandī political involvement, see Dina Le Gall, "Forgotten Naqshbandīs and the Culture of Pre-Modern Sufi Brotherhoods," Studia Islamica 97 (2003).

76 Christoph Kleine and Monika Wohlrab-Sahr, "Research Programme of the HCAS 'Multiple Secularities - Beyond the West, Beyond Modernities"' Working Paper Series HCAS "Multiple Secularities - Beyond the West, Beyond Modernities" 1 (Leipzig University, 2016), 8; see too Armando Salvatore, "The Euro-Islamic Roots of Secularity: A Difficult Equation," Asian Journal of Social Science 33, no. 3 (2005). 
In Armando Salvatore's explanation, secularity “manifests itself most directly in concrete modes of governance, and in the way religion is reconstructed as experience and belief to be confined to the private sphere of life."77

Kāshifīs account of an encounter between two rival Tīmūrid princes, Abū Sa īid (r. 1451-69) in Samarqand and Abū al-Qāsim Bābur (r. 1447-57), who ruled in Khurāsān, is telling in this regard. Faced with an imminent attack from Bābur's forces, Abū Sa īd asked 'Ubayd Allāh Aḥrār for advice. The military commanders in his service had ruled out resistance as futile, and advised the sultan to seek refuge in Turkestan. Ahrār disagreed, and said: "I have assumed the task of defeating Bābur. Rest assured: I will fulfill my task." The commanders protested, but the Sufi shaykh prevailed because, we are told, the sultan was steadfast in his conviction. The commanders of Bābur's army knew that Abū Sa 'īd's forces would not survive in battle against them. They were certain that his commanders would arrange his escape from Samarqand, and planned their attack on that basis. As Bābur's army descended on the city, Abū Sa'īd's soldiers were dispersed in various neighborhoods. The people of Samarqand put up a fierce resistance, and as instructed, proceeded to cut off the nose and ears of each captured soldier. Bābur's army was in despair. Then a cholera epidemic befell their horses and the trenchant smell of decaying corpses exacerbated their misery. Bābur sent an emissary to Ahrār to sue for peace. ${ }^{78}$

But the story does not end there. As the vanquished Bābur lay on his side outside the city walls, he is said to have cried out:

It may be true that we did not conquer Samarqand, but we did learn the truth about Khwāja Ahrār, who is not an 'ârif, for if he were, he would not have destroyed us so.

Ahrār's retort in defense of his spiritual credentials elevated the status of Sufi saints to that of prophets:

Like prophets, 'ârifs are judged by the cause not the consequence of their actions. For if it weren't so, justifying the destruction wrought by the likes of Noah and Hūd who destroyed their own people by water and wind would be a problem. ${ }^{79}$

77 Armando Salvatore, "The Euro-Islamic Roots of Secularity," 415. The Sufi exception to Salvatore's definition - their espousal of a distinctly public master-disciple relationship alongside an internalized religious experience based on individual practice - is addressed in more detail in the following section.

78 Rashahāt, II, 522-24.

79 Rashahāt, II, 525-26. 
To support his claim, Aḥrār cites Q 8:11, which, addressing the believers, claims that it was not they who killed the unbelievers, but God himself.

In this episode, Ahrār emerges as the true ruler of Samarqand, the people of the city his true army, and their truth confirmed by divine intervention. The mandate of restraining rulers, and its handmaiden, promoting the common good, is only feasible if religious leaders engage with political life - a nexus of secularity in early modern Islamic political thought. Restraining rulers denotes a differentiated notion of society, for it recognizes a political realm that must be tamed by religion, and an ideational sphere of religion which must be tempered to make good government possible. Crucially, however, it does not formulate a secular society, from which religion is segregated. Instead, Kāshifïs Rashaḥāt 'ayn al-ḥayāt constructs a public piety that, although in tension with politics, eschews a secular/ religious divide.

\section{New Pieties}

That the religious landscape of Iran was drastically transformed in the period between the Mongol invasions and the coming of the Șafavids, originally leaders of a Sufi movement, is self-evident. Most conventional accounts read that history as a gradual migration from Sunnism to Shi'ism, facilitated by "Twelver Sunni" religious leaders or creeds that combined Sunni dogma with elements of the Shi' $i$ faith. ${ }^{80}$ These 'syncretistic' creeds and actors paved the way for a full-scale conversion by spending hundreds of years warming Iranian hearts to a Shi' ism-lite, a creed fused with philo'Alidism, spirituality, and reverence for human agents, from imams to Sufi pirs (masters). Algar has argued against both the claim that Sufi communities prepared Iran for conversion to the Shi'i creed, and the

80 The term was coined by Muhammad Ja far Mahjūb, cited in Algar, "The Naqshbandis and Safavids," 31; for a rebuttal of the 'soft Sunnism' hypothesis from a different angle, see Sajjad Rizvi, "Before the Safavid-Ottoman Conflict: Jāmī and Sectarianism in Timurid Iran and Iraq," in Jāmī in Regional Contexts, 227-30; and for the Sunnitization of Shi' ism in the Islamic west exemplified in the Almohad conception of authority in the $12^{\text {th }}$ and $13^{\text {th }}$ centuries, see Maribel Fierro, “The Legal Policies of the Almohad Caliphs and Ibn Rushd's Bidayat al-mujtahid," Journal of Islamic Studies 10, no. 3 (1999), and her "The Almohads and the Fatimids," in The Almohad Revolution: Politics and Religion in the Islamic West during the Twelfth-Thirteenth Centuries, ed. Maribel Fierro (London: Routledge, 2012). 
claim that Iran would have converted with or without the Shi'i Șafavids at its helm. His view rests to a very large extent on what he sees as the Sunni zeal of the Naqshbandi Sufis. ${ }^{81}$ The predominance of the fiercely Sunni Naqshbandi Sufis in the region, he writes, should have sufficed to prevent any warming to the Shi' $\mathrm{i}$ cause. However, Safavid Shi'ism was just one of a plethora of new pieties that took hold in the $14^{\text {th }}$ century, a good number of which were not 'syncretistic' and looked not to reconcile but to override differences among communities of Muslims.

One such piety is the Mughal emperor Akbar's (r. 1556-1605) much-

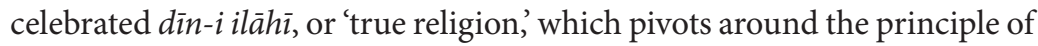
sulh-i kull, or universal conciliation. Against the prevailing consensus that places the impetus for such cross-confessionalism in the Mughal court and its interest in preserving public peace, Abbas Amanat has recently suggested that the agnostics at Akbar's court, such as the Nuqtawis, played a more significant role in its formulation than previously considered. Pointist Nuqțawī cosmology "advanced a theory of mystical materialism and cyclical renewal that essentially called for a renewed humanist creed beyond the pale of Islamic dispensation." ${ }^{22}$ Brought to India by Iranian scholars fleeing Șafavid persecution, Nuqțawī doctrine was naturalized in India's multi-confessional religious landscape as it spread among Sufi communities. A particularly influential individual was the Nuqțawī scholar, Mīr Sayyid Sharī Āmulī (d. 1625) who arrived at Akbar's court in 1576. According to Amanat, Āmulī persuaded Akbar that kingship, as a reflection of the divine, should incorporate the full gamut of diverse creeds, but this may be overstating Āmulī's reach.

Equally emblematic of the new pieties is the politically active and apocalyptic Ḥurūfiyya (Lettrist) movement founded by Faḍl Allāh Astrābādī, who claimed to have received the full meaning of Muhammad's message in a revelation, and was executed for this and other such innovative beliefs by the Tìmūrid governor of Azerbaijan in 1394. His followers were particularly influential among the Bektashi Sufis in the Ottoman

81 Algar, "The Naqshbandis and Safavids," 32.

82 Abbas Amanat, "Persian Nuqtawīs and the Shaping of the Doctrine of 'Universal Conciliation' (SULH-I KULL) in Mughal India," in Unity in Diversity: Mysticism, Messianism and the Construction of Religious Authority in Islam, ed. Orkhan Mir-Kasimov (Leiden: Brill, 2014), 367. 
empire. ${ }^{83}$ Although the so-called Hurūfiyya were considered a heresy and decried in mainstream historical sources, the innovations in their creed were, for the most part adoptions of Shi'i tenets. These included ta'wil (in Shi' $i$ creed, the ability to bridge the inner and outer meanings of prophetic revelation, a privilege granted specifically to the imams), the imam as the manifestation of the divine word and spiritual guide, the means by which the divine attributes can be known, as well as the eschatological witnesses which will explain all the Qur'an's ambiguities at the end of time. ${ }^{84}$ In his testament, Astrābādī compares himself to Ḥusayn b. 'Alī, Muhammad's grandson who was killed in battle in 680 and the paradigmatic martyr of Shi'i Islam. ${ }^{85}$

In Egypt, overcoming sectarian differences and active involvement in the design and practice of politics was the Sufi master 'Abd al-Wahhāb alSha'rānī’s (d. 1565) project. Sha'rānī was close to two Sufi communities of his day, the Shādhilīs and the Ahmadīs, and although a prolific writer, he never professed his own affiliation. ${ }^{86}$ Samuela Pagani has suggested that Al-Sha'rānī's project in his hagiographical treatise, al-Mīzān al-kubrā', was to arrive at a synthesis between the legal and spiritual traditions in Islam. ${ }^{87}$ To that end, al-Sha'rānī resorted to a "wide language" (kalām wāsi') to bridge between the madrasa (colleges of Islamic legal and theological learning) and the zāwiya (Sufi gathering sites), popular and high Islam, and to publicize esoteric Sufi doctrine in a form that was palatable to the literalist (zâhirī) 'ulamā'.

83 For more on the Hurūfĩ creed and its history, see Hamid Algar, "Horufism," Encyclopaedia Iranica Online, accessed June 4, 2019. Originally published December 15, 2004. http://www.iranicaonline.org/articles/horufism.

84 Aḥmad Ṭāhirī 'Irāqī, "Introduction," in Khwāja Muhammad Pārsā-yi Bukhārāī, Qudsiyya, ed. Aḥmad Ṭāhirī 'Irāqī (Tehran: Tahuri, 1975), 24-25; and Orkhan Mir-Kasimov, "Ummīs versus Imāms in the Ḥurūfī Prophetology: An Attempt at a Sunnī/Shīī Synthesis?" in Unity in Diversity: Mysticism, Messianism and the Construction of Religious Authority in Islam, ed. Orkhan Mir-Kasimov (Leiden: Brill, 2014).

85 Shahzad Bashir, Fazlallah Astrabadi and the Hurufis (Oxford: Oneworld, 2005), 39-40.

86 For al-Sha'rānīs biography, see the introduction to Al-Sha'rānī, 'Abd al-Wahhāb ibn Ahmad ibn 'Alī, Advice for Callow Jurists and Gullible Mendicants on Befriending Emirs, trans. Adam Sabra (New Haven: Yale University Press, 2017); and for his political activities, see Neguin Yavari, "Sufis as Court Advisors," in Handbook of Sufi Studies: Sufi Institutions, ed. Alexandre Papas (Leiden: Brill, forthcoming 2020).

87 Samuela Pagani, "The Meaning of the ikhtiläf al-madhāhib in 'Abd al-Wahhāb alSha'rānīs al-Mìzān al-kubrā'”, Islamic Law and Society 11, no. 2 (2004). 
A similar argument lies at the heart of Armando Salvatore's distinction between the rival ethics of $a d a b$ and hadith inspired moralism,

a rather 'soft' distinction, whereby the ethical and literary tradition of $a d a b$ works as an harmonious counterpoint more than as a sheer alternative, to the normative discourse subsumed under the notion of sharia, the law originating from Divine will (shar) ${ }^{88}$

That soft distinction has forged differentiations, even if ambivalent and uncertain, between religion and other spheres of human activity, including politics, law, art, and the economy.

\section{Global New Pieties?}

In thinking about the Naqshbandīs and other Sufi communities as agents of religious change in the early modern period in global terms, ${ }^{89}$ our attention is quickly drawn to the confessionalization paradigm put forward by Heinz Schilling and others to explain the role of religion in modern European history. There too, religion at the service of politics, at religion's instigation, is a constitutive element. In brief, Schilling argues that the end of the $16^{\text {th }}$ century witnessed the birth of three or four confessional churches that belong squarely to Europe's modern history: the Lutheran Church, the Calvinist/Reformed Church, the Tridentine Catholic Church, and the Anglican Church. The new churches divided Europe into distinct cultural religious systems, gave birth to a new state system, redefined political identities and spawned new nations. Confessional Europe may have been Christian for seventeen centuries, but the dawn of secularization in the $18^{\text {th }}$ century that marked the beginning of modern Europe would not have taken hold had it not been for confessionalization..$^{90}$

88 Armando Salvatore, "The Islamicate Adab Tradition vs. the Islamic Shari'a, from Pre-Colonial to Colonial," Working Paper Series of the HCAS "Multiple Secularities - Beyond the West, Beyond Modernities” 3 (Leipzig University, 2018), 7.

89 Alan Strathern, "Global Early Modernity and What Came Before," Past \& Present 238, no. 13 (2018).

90 Heinz Schilling, Early Modern European Civilization, 11-32; and his "Confessionalization: Historical and Scholarly Perspectives of a Comparative and Interdisciplinary Paradigm, " in Confessionalization in Europe, 1555-1700: Essays in Honor and Memory of Bodo Nischan, ed. John M. Headley, J. Hillerbrand and Anthony J. Papalas (Aldershot, UK: Ashgate, 2004), 21-35, and Thomas A. Brady, Jr. "Confessionalization - The Career of a Concept," in Confessionalization in Europe, 1555-1700: Essays in Honor and Memory 
For the most part incorrectly, in my opinion, recent discussions on confessionalization in the Islamic world take the paradigm to imply an intensification of confessional strife and are focused on the fostering of sectarian identity by the Ottoman, Safavid and Mughal states in the $16^{\text {th }}$ century. A number of those studies are reviewed in a recent Past \& Present review article by Chris Markiewicz. ${ }^{91}$ What Markiewicz fails to note, however, is that confessionalization crystallizes on the social register rather than in government policy, and that as such, the impetus for a wellbounded confessional identity comes from religious actors, be it Aquinas' disciple Ptolemy of Lucca (d. 1327), or his near contemporary at the İlkhānid court, 'Alä' al-Dawla Simnānī. In this vein, the new Sufi madhhab is confessional, that is, it believes in the truth of its creed as well as its superiority to its many competitors, but also promotes a universal religion that is open to all, accommodates public peace and prioritizes the common good.

The majority of the new pieties that marked early modern Islamic history may have been short-lived and unsuccessful in birthing new religions (Babis and Bahais are notable $19^{\text {th }}$-century exceptions). But they were instrumental in crafting new molds of pious behavior, focused on individual practice, and centered around a politically active and intensely mobile individual leader. ${ }^{92}$ They also begat secularity. ${ }^{93}$ As Reinhard Schulze has demonstrated, the new pieties spawned modern confessional conceptions of religious identity in the

of Bodo Nischan, ed. John M. Headley, J. Hillerbrand and Anthony J. Papalas (Aldershot, UK: Ashgate, 2004), 1-20.

91 Christopher Markiewicz, "Europeanist Trends and Islamicate Trajectories in early Modern Ottoman History," Past \& Present 239, no. 1 (2018). See too Nile Green, "Islam in the Early Modern World," in The Cambridge World History, ed. Jerry H. Bentley, Sanjay Subrahmanyam, and Merry E. Wiesner-Hanks (Cambridge: Cambridge University Press, 2015); and for another unconvincing application of the confessionalization paradigm to the Middle East, see Ayşe Baltacioğlu, "Formation of Kizilbaş Communities in Anatolia and Ottoman Responses, 1450s-1630s," International Journal of Turkish Studies 20, no. 1-2 (2014).

92 The kinetic energy of the Sufi masters and their proselytizing agents who crisscrossed the Islamic lands on a regular basis recalls the role of religious immigrants in creating the entrepreneurial class of the new capitalist cities of Europe in the $17^{\text {th }}$ century, see Hugh Trevor-Roper, The Crisis of the Seventeenth Century: Religion, the Reformation and Social Change (Indianapolis: Liberty Fund, 1999), 28-42.

93 Reinhard Schulze, "The Ambiguity of the Religious Self in Pre- and Postnational Social Worlds: Examples from $17^{\text {th }}$-Century Morocco and $20^{\text {th }}$-Century Germany" (lecture, $16^{\text {th }}$ Annual Conference of the European Association for the Study of Religions, Bern, June 17, 2018); and idem, "Islam and the Global History of Secularity" (lecture, Conference on "Secularities - Patterns of Distinction, Paths of Differentiation" convened by the HCAS "Multiple Secularities - Beyond the West, Beyond Modernities," Leipzig, October 5, 2018). 
$16^{\text {th }}$ and $17^{\text {th }}$ centuries, that by the $19^{\text {th }}$ century, led to the emergence of national identities, and in time, the rise of nation states. What is genuinely at stake in recasting the religious history of the early modern Islamic world is not simply a call for new, improved labels, a cleverly angulated composite noun to supplant 'syncretistic,' 'hybrid,' or 'synthesis.' Rather, the hope is for a paradigm of religious change that is not restricted to a spectrum stretching from Sunnism to Shi' ism, along which pieties of dazzling variety may be plotted.

In the longer run, this felicitous turn may finally put to rest the seemingly interminable quest for Islamic secularism, or for an indigenous enlightenment. ${ }^{94}$ We may be able to stop asking, as Amanat does in his study on Nuqțawi influence at the Mughal court, why it was that "the agnostic trend of the early modern Persianate world differed from [its] equivalents in Europe of the $16^{\text {th }}$ and $17^{\text {th }}$ centuries," and failed to produce "a lasting philosophical movement similar to the early Enlightenment in such places as the Dutch Republic,"95 and instead consider the Enlightenment

less as the birthplace of secularism than as the birthplace of a distinctly modern form of religion whose presence and power continues to shape the present. ${ }^{96}$

How will our understanding of modern religion change if, in line with the aforesaid, modern confessions such as Bahaism and Salafism are considered in tandem as equally a part of modern Islam?

The new pieties of the early modern period demand not just a thorough revision of how the history of Sufi movements and practices is studied, and a reevaluation of categories and concepts used to differentiate religious

94 Albrecht Hofheinz has argued that Sufi movements (what he, following Reinhard Schulze, calls Neo-Sufi movements) of the $18^{\text {th }}$ and $19^{\text {th }}$ centuries differed sufficiently from their earlier counterparts to successfully catalyze an Islamic Enlightenment. They shared an agenda with Pietists - especially the American Methodists - that included: "Carrying the simple (and simplified) message of Truth beyond the sterile debating rooms of the theologians, carrying it to the common people, implementing it in real life, [and] making every individual responsible for its implementation;" see "Illumination and Enlightenment Revisited, or: Pietism and the Roots of Islamic Modernity," 18. Nile Green has noted several differences between Western mysticism and Sufism regarding the latter's collective and public rather than individualistic and private aspects, see his Sufism: A Global History, 1-10. For more on the Naqshbandis in that period, see Waleed Ziad, "From Yarkand to Sindh via Kabul: The Rise of Naqshbandi-Mujaddidi Sufi Networks in the Eighteenth and Nineteenth Centuries, in The Persianate World: Rethinking a Shared Sphere, Abbas Amanat and Assef Ashraf, eds. (Leiden: Brill, 2019), 125-68.

95 Amanat, "Persian Nuqtawīs and the Shaping of the Doctrine," 389.

96 Sheehan, "Enlightenment, Religion, and the Enigma of Secularization," 1080. 
movements and identities, but also a rethinking of Islamic history in the context of global history. Even if convergence between various parts of the early modern world - in both what came before early modernity and what came after it - remains elusive, a comparative approach to religious change may help illuminate global currents that defy easy categorization and, crucially, predate the empire-building impulse that for many early modernists sculpts their era from what came before it. ${ }^{97}$

Focusing on religious change will also force a reconsideration of arguments premised on absence of one sort or another. The absence of institutions - no matter how broadly defined ${ }^{98}$ - is one example, as it has been taken to explain why it was that Islamic societies missed the boat to modernity, secularization and, ultimately democracy. Eduardo Manzano's study on the different processes of institutionalization in the medieval Christian and Islamic worlds is a case in point. While institutions served as engines of growth in $14^{\text {th }}$-century Europe, he writes, they failed in the Islamic world,

because of the separation between power and authority that emerged at an early and critical stage in the Islamic polity; and, the distinctive notion of community that emerged as a result of this and helped to shape the self-definition of Muslim societies and the making of the social regularities that performed processes of institutionalization in early Islam. ${ }^{99}$

Manzano's thesis - that strong states grew to dominate the Christian lands whereas states in the Islamic world remained weak as religion successfully monopolized the discourse in authority - has been the mantra of scholarship on the Islamic world for almost a century.

97 In his defense of the 'Cambridge method' against accusations of insularity and Eurocentrism, J. G. A. Pocock suggests an axial age common to several civilizations around the globe, which was succeeded, "circa 1500-1700, by an age of global empire, in which European commerce dominated the global ocean and permitted economic and political domination of the world's cultures." See J. G. A. Pocock, "On the Unglobality of Contexts: Cambridge Methods and the History of Political Thought," Global Intellectual History 4, no. 1 (2018): 7; and for an opposing view, see John Dunn, "Why We Need a Global History of Political Thought," in Markets, Morals, Politics: Jealousy of Trade and the History of Political Thought, ed. Béla Kapossy et al. (Cambridge: Harvard University Press, 2018).

98 For a range of possibilities for what can be defined as an institution, see Gadi Algazi, "Comparing Medieval Institutions: A Few Introductory Remarks," in Diverging Paths? The Shapes of Power and Institutions in Medieval Christendom and Islam, ed. John Hudson and Ana Rodríguez (Leiden: Brill, 2014), 5-7.

99 Eduardo Manzano, "Why Did Islamic Medieval Institutions Become So Different from Western Medieval Institutions," Medieval Worlds 1 (2015): 127. 
In important ways, the reach of this new approach is more modest, although it extends beyond the question raised by Gadi Algazi:

Can we engage in large-scale comparisons between societies and even groups of historical societies and ask why they changed in one and not the other without assuming the superiority of one particular historical path, without taking this path for granted even while rejecting any value judgements, and without reducing alternative trajectories to no more than the roads not taken? ${ }^{100}$

The new approach calls for new strategies of reading that will, one hopes, give rise to better questions, and a modern conceptual lexicon for rethinking the past. Any attempt at globalizing Islamic history, be it premised on exchange, influence, cross-pollination, or combinative, ${ }^{101}$ will ultimately rest on globalizing - read modernizing - its historiographical apparatus. And that is where we must begin.

100 Gadi Algazi, “Comparing Medieval Institutions," 3.

101 For more on the various attempts to capture the infrastructure of cross-cultural exchange in the premodern period, see James E. Montgomery, "Islamic Crosspollinations," in Islamic Crosspollinations: Interactions in the Medieval Middle East, ed. James. E. Montgomery, Anna Akasoy and Peter E. Pormann, (Cambridge: E. J. W. Gibb Memorial Trust, 2007), 148-93; and Catherine Holmes and Naomi Standen, "Introduction: Towards a Global Middle Ages," Past \& Present 238, Issue supplement 13 (2018). 



\section{Bibliography}

Aigle, Denise. The Mongol Empire

Between Myth and Realities, Historic

Anthropological Studies. Leiden:

Brill, 2014.

Aigle, Denise. “'Atțār's Tadhkirat al-awliyā' and Jāmī's Nafaḥāt al-uns: Two Visions of Sainthood." Oriente Moderno 96, no. 2 (2016): 271-315.

Algar, Hamid. "Silent and Vocal dhikr in the Naqshbandī Order." In Akten des VII. Kongresses für Arabistik und Islamwissenschaft, Göttingen, 15.-22. August 1974. Edited by Albert Dietrich, 39-46. Göttingen: Vandenhoeck \& Ruprecht, 1976.

Algar, Hamid. "The Naqshbandis and Safavids: A Contribution to the Religious History of Iran and Her Neighbors." In Safavid Iran and her Neighbors. Edited by Michel Mazzaoui, 7-48. Salt Lake City: University of Utah Press, 2003.

Algar, Hamid. "Horufism.” In Encyclopaedia Iranica Online, accessed June 4, 2019. Originally published December 15, 2004. http://www. iranicaonline.org/articles/horufism.

Algar, Hamid. Review of A Culture of Sufism: Naqshbandis in the Ottoman World, 1450-1750, by Dina Le Gall's, Journal of Islamic Studies 18, no. 3 (2007): 414-420.

Algar, Hamid. "Abū Ya'qūb Yūsuf b. Ayyūb Hamadānī,” In Encyclopaedia Iranica Online, accessed June 4, 2019. Originally published July 21, 2011. http://www.iranicaonline.org/ articles/abu-yaqub-hamadani.

Algar, Hamid. Jāmī. Delhi: Oxford University Press, 2013.

Algar, Hamid. Review of The Nativist Prophets of Early Islamic Iran: Rural Revolt and Local Zoroastrianism, by Patricia Crone, Journal of Shi' a Islamic Studies 8, no. 3 (2015): 367-378.
Algazi, Gadi. "Comparing Medieval Institutions: A Few Introductory Remarks." In Diverging Paths? The Shapes of Power and Institutions in Medieval Christendom and Islam. Edited by John Hudson and Ana Rodríguez, 3-15 Leiden: Brill, 2014.

Ali, Abdullah Yusuf. The Meaning of the Glorious Quran, accessed June 4, 2019. http://www.islam101.com/ quran/yusufAli/QURAN/9.htm.

Amanat, Abbas. "Meadow of the Martyrs: Kāshifî̀s Persianization of the Shi 'i Martyrdom Narrative in the Later Tīmūrid Herat." In Culture and Memory in Medieval Islam: Essays in Honour of Wilferd Madelung. Edited by Farhad Daftary and Josef W. Meri, 250-75. London: I. B. Tauris, 2003.

Amanat, Abbas. "Persian Nuqțawīs and the Shaping of the Doctrine of 'Universal Conciliation' (SULH-I KULL) in Mughal India." In Unity in Diversity: Mysticism, Messianism and the Construction of Religious Authority in Islam. Edited by Orkhan MirKasimov, 367-93. Leiden: Brill, 2014.

Ibn al-Athīr, 'Izz al-Dīn Abū al-Ḥasan, The Annals of the Saljūq Turks. Translated by D. S. Richards. London: Routledge 2002.

Baltacioğlu, Ayşe. "Formation of Kizilbaş Communities in Anatolia and Ottoman Responses, 1450s-1630s." International Journal of Turkish Studies 20, no. 1-2 (2014): 21-48.

Bashir, Shahzad. Fazlallah Astrabadi and the Hurufis. Oxford: Oneworld, 2005.

Bashir, Shahzad. Sufi Bodies: Religion and Society in Medieval Islam. New York: Columbia University Press, 2013.

Beveridge, H. "The Rashahāt-i'Ain alHayāt (Tricklings from the Fountain of Life)." Journal of the Royal Asiatic Society 48, no. 1(1916): 59-75. 
Brady Jr., Thomas A. "Confessionalization - The Career of a Concept." In Confessionalization in Europe, 15551700: Essays in Honor and Memory of Bodo Nischan, Edited by John M. Headley, J. Hillerbrand, and Anthony J. Papalas, 1-20. Aldershot, UK: Ashgate, 2004.

Bulliet, Richard W. Islam: The View from the Edge. New York: Columbia University Press, 1993.

Chamberlain, Michael. Knowledge and Social Practice in Medieval Damascus, 1190-1350. Cambridge: Cambridge University Press, 1994.

Chih, Rachida. "Discussing the Sufism of the Early Modern Period: A New Historiographical Outlook on the Tariqa Muhammadiyya." In Sufism East and West: Mystical Islam and Cross-Cultural Exchange in the Modern World. Edited by Jamal Malik and Saeed Zarrabi-Zadeh, 104-28. Leiden: Brill, 2019.

DeWeese, Devin. "The Legitimation of Bahā' al-Dīn Naqshband," Asia-tische Studien 50, no. 2 (2006): 261-305.

DeWeese, Devin. "Spiritual Practice and Corporate Identity in Medieval Sufi Communities of Iran, Central Asia, and India: The Khalvatī/'Ishqī/Shațtāīi Continuum.” In Religion and Identity in South Asia and Beyond: Essays in Honor of Patrick Olivelle. Edited by Lindquist Steven E., 251-300. London; New York; Delhi: Anthem Press, 2011.

DeWeese, Devin. "Re-Envisioning the History of Sufi Communities in Central Asia: Continuity and Adaptation in Sources and Social Frameworks, $16^{\text {th }}-20^{\text {th }}$ Centuries." In Sufism in Central Asia: New Perspectives on Sufi Traditions, $15^{\text {th }}-21^{\text {st }}$ Centuries. Edited by Devin DeWeese and Jo-Ann Gross, 21-74. Leiden: Brill, 2018.
d'Hubert, Thibaut, and Alexandre Papas, eds. Jāmī in Regional Contexts, The Reception of 'Abd al-Rahmmān Jämì's Works in the Islamicate World, ca. $9^{\text {th }} / 15^{\text {th }}-14^{\text {th }} / 20^{\text {th }}$ Century. Leiden: Brill, 2018.

Al-Dhahabī, Shams al-Dīn b. Muhammad. Siyar a'lām al-nubalā'. Edited by S. al-Arna'ut, and H. al-Asad. Beirut: Risala, 1984.

Dunn, John. "Why We Need a Global History of Political Thought." In Markets, Morals, Politics: Jealousy of Trade and the History of Political Thought. Edited by Béla Kapossy, Isaac Nakhimovsky, Sophus A. Reinert, and Richard Whatmore, 285-310. Cambridge: Harvard University Press, 2018.

Elias, Jamal J. The Throne Carrier of God: The Life and Thought of 'Alä' ad-dawla al-Simnānī. Albany: State University of New York Press, 1995.

Ephrat, Daphna. "Religious leadership and Associations in the Public Sphere of Seljuk Baghdad.” In The Public Sphere in Muslim Societies. Edited by Miriam Hoexter, Shmuel N. Eisenstadt, and Nehemia Levtzion, 31-48. Albany: State University of New York Press, 2002.

Al-Fārisī, Abū al-Ḥasan 'Abd al-Ghāfir b. Ismā'îl al-Hāfiz. "Ta’rīkh al-Nīsābūr: al-muntakhab min al-siyāq." In The Histories of Nishapur. Edited by Richard Frye. London: Mouton, 1965.

Fierro, Maribel. “The Legal Policies of the Almohad Caliphs and Ibn Rushd's Bid yat almujtahid." Journal of Islamic Studies 10, no. 3 (1999): 226-48.

Fierro, Maribel. "The Almohads and the Fatimids." In The Almohad Revolution: Politics and Religion in the Islamic West during the Twelfth-Thirteenth Centuries. Editey by Maribel Fierro. London: Routledge, 2012. 
Franke, Patrick. Begegnung mit Khidr: Quellenstudien zum Imaginären im traditionellen Islam. Stuttgart: Steiner, 2000.

Garçin, Jean-Claude. Espaces, pouvoirs et idéologies de l'Égypte médiévale. London: Variorum Reprints, 1987.

Gramlich, Richard. Adab al-mulük: Die Lebensweise der Könige. Translated and edited by Richard Gramlich. Stuttgart: Kommissionsverlag Steiner, 1993.

Green, Nile. "The Dilemmas of the Pious Biographer: Missionary Islam and the Oceanic Hagiography." Journal of Religious History 34, no. 4 (2010): 383-397.

Green, Nile. "Islam in the Early Modern World." In The Cambridge World History. Edited by Jerry H. Bentley, Sanjay Subrahmanyam, and Merry E. Wiesner-Hanks, 358-86. Cambridge: Cambridge University Press, 2015.

Green, Nile. Sufism: A Global History. Chichester, West Sussex: WileyBlackwell, 2012.

Gross, Jo-Ann. "The Naqshbandìya and Khwāja 'Ubayd Allāh Aḥrār.” In Ubayd Allāh ibn Maḥmūd Aḥrār, The Letters of Khwāja 'Ubayd Allāh Ahrār and His Associates. Edited by Jo-Ann Gross and Asom Urunbaev, 1-22. Leiden: Brill, 2004.

Ḥakīm Samarqandī, Abū al-Qāsim Ishāq b. Muhammad. Tarjumah-i al-Sawād al-a'zam. Edited by 'Abd al-Hayy Habibi. Tehran: Bunyad Farhang Iran, 1969.

Henderson, Martha L. "What is Spiritual Geography?" Geographical Review 83, no. 4 (1993): 469-472.

Holmes, Catherine and Naomi Standen, "Introduction: Towards a Global Middle Ages." Past \& Present 238, Issue supplement 13 (2018): 1-44. Jāmī, Nūr al-Dīn, 'Abd al-Raḥmān. Nafaḥāt al-uns min ḥaḍarāt al-quds. Edited by Mahmud 'Abidi. Tehran: Ittila‘at, 1991.
Ibn al-Jawzī, Abū al-Faraj 'Abd alRaḥmān. Al-Muntazam fī tā'rīkh al-mulūk wa al-'umam. Hyderabad-Deccan: Osmania Oriental Publishers, 1939-41.

Al-Jurfādiqānī, Abū al-Sharaf Nāṣih b. Zafar. Tarjumah-i Tārīkh-i Yamīnì. Edited by Muhammad Ja'far Shi'ar. Tehran: Bungah Tarjumah wa Nashr Kitab, 1978.

Kāshifī, Fakhr al-Dīn al-Ṣafī 'Alī b. Ḥusayn Wāi'ż. Rashahāt 'ayn al-hayāt. Edited by 'Ali Asghar Mu'iniyan. 2 vols. Tehran: Bunyad Nikukari Nuriyani, 1977.

Al-Kāshifī, 'Alī b. al-Ḥusayn al-Wā’iz alȘafī. Tarjamat Rashahāt 'ayn al-hayāt, Translated by Muhammad Murad al-Qazini al-Manzilawi. Mecca: Matbáa al-Muhammadiya, 1882 or 1883.

Kashifi, Mawlana Ali ibn Husain Safi, Beads of Dew form the Source of Life. Translated by Muhtar Holland. Oakland Park, CA: Al-Baz Publishers, 2001.

Khaleghi-Motlagh, Djalal. "Asadī Țūsī 2," Majallah-i Dānishkadah-i adabiyāt va 'ulūm-i insānī Dānishgāh Firdawsī 14: 1 (1978): 68-130.

Khismatulin, Alexei A. “The Alchemy of Happiness': Al-Ghazālī’s Kìmīyā and the Origins of the Khwājagān-Naqshbandiyya Principles."In Ideas, Images, and Methods of Portrayal. Edited by Sebastian Günther, 228-71. Leiden: Brill, 2015.

Kleine, Christoph and Monika WohlrabSahr, "Research Programme of the HCAS Multiple Secularities Beyond the West, Beyond Modernities.” Working Paper 1, March 1, 2016.

Krasnowolska, Anna. "Keżr,” Encyclopaedia Iranica Online, accessed June 4, 2019. Originally published April 15, 2009. http://www.iranicaonline. org/articles/kezr-prophet.

Lazard, Gilbert. "The Rise of the New Persian Language." In The Cambridge His- 
tory of Iran, Volume 4, The Period from the Arab Invasion to the Saljūqs. Edited by R. N. Frye, 595-632. Cambridge: Cambridge University Press, 1975.

Le Gall, Dina. "Forgotten Naqshbandīs and the Culture of Pre-Modern Sufi Brotherhoods." Studia Islamica 97 (2003): 87-119.

Le Gall, Dina. A Culture of Sufism: Naqshbandīs in the Ottoman World, 1450-1700. Albany: State University of New York Press, 2005.

Lotman, Yuri M. Universe of the Mind: A Semiotic Theory of Culture. Bloomington: Indiana University Press, 1990.

Manz, Beatrice Forbes. "Tamerlane and the Symbolism of Sovereignty." Iranian Studies 21, no. 1-2 (1988): 105-22.

Madelung, Wilferd. "Abu'l-Qāsem Esḥāq Samarqandi." Encyclopaedia Iranica Online, accessed June 4, 2019. Originally published December 15, 1983. http://www.iranicaonline.org/articles/abul-qasem-eshaq.

Madelung, Wilferd. "Yūsuf alHamadānī and the Naqšbandiyya," Quaderni di Studi Arabi 5, no. 6. 1987-1988.

Manzano, Eduardo. "Why Did Islamic Medieval Institutions Become So Different from Western Medieval Institutions?" Medieval Worlds 1 (2015): 118-37.

Markiewicz, Christopher. "Europeanist Trends and Islamicate Trajectories in early Modern Ottoman History," Past \& Present 239, no. 1 (2018): 265-81.

Martini, Maria Giovanni. 'Alā al-Dawla al-Simnānī between Spiritual Authority and Political Power: A Persian Lord and Intellectual in the Heart of the İlkhānate. Leiden: Brill, 2017.

Meier, Fritz. Zwei Abhandlungen über die Naqšbandiyya. Istanbul: Franz Steiner Verlag, 1994.

Melville, Charles. "Concepts of Government and State Formation in
Medieval Iran." In Iran after the Mongols. Edited by Sussan Babaie, 33-54. London: I. B. Tauris, 2019.

Mir-Kasimov, Orkhan. "Ummīs versus Imāms in the Ḥurūfī Prophetology: An Attempt at a Sunnī/Shī'ī Synthesis?" In Unity in Diversity: Mysticism, Messianism and the Construction of Religious Authority in Islam. Edited by Orkhan Mir-Kasimov, 221-47. Leiden: Brill, 2014.

Mojaddedi, Jawid A. The Biographical Tradition in Sufism: The tabaqāt genre from al-Sulamì to Jamì. Richmond, Surrey: Curzon Press, 2001.

Montgomery, James. E. "Islamic Crosspollinations." In Islamic Crosspollinations: Interactions in the Medieval Middle East. Edited by James E. Montgomery, Anna Akasoy and Peter E. Pormann, 148-93. Cambridge: E. J. W. Gibb Memorial Trust, 2007.

Ibn al-Munawwar, Muhammad b. Abū Sa'd. Asrār al-tawhīd. Edited by Muhammad Rida Shafi'i-Kadkani. Tehran: Agah, 1987.

Nguyen, Martin, and Matthew Ingalls, eds. "Al-Qushayrī and His Legacy." Special Issue, Journal of Sufi Studies 2, no. 1 (2013).

Ohlander, Erik S. Sufism in an Age of Transition: 'Umar al-Suhrawardī and the Rise of the Islamic Mystical Brotherhoods. Leiden: Brill, 2008.

Pagani, Samuela. "The Meaning of the ikhtiläf al-madhāhib in 'Abd al-Wahhāb al-Sha'rānī's al-Mìzān al-kubrä'," Islamic Law and Society 11, no. 2 (2004): 177-212.

Pārsā, Khwāja Muhammad. Faṣl al-Kh$i t a \bar{b} b$. Tashkent: Litografiya Gulam Khasandzhanova, 1913.

Paul, Jürgen. Doctrine and Organization: The Khwājagān/Naqshbandìya in the First Generation after Bahä'uddīn. Berlin: Das Arabische Buch, 1998. 
Paul, Jürgen. “'Alī b. Husayn al-Wāì al-Kāshifí.” In Encyclopaedia of Islam, THREE. Edited by Kate Fleet, Gudrun Krämer, Denis Matringe, John Nawas, and Everett Rowson, 2009.

Paul, Jürgen. "The Rise of the Khwajagan-Naqshbandiyya Sufi Order in Timurid Herat." In Afghanistan's Islam: From Conversion to the Taliban. Edited by Green Nile, 71-86. Oakland, California: University of California Press, 2017.

Patrizi, Luca. “Adab al-mulūk: L'utilisation de la terminologie du pouvoir dans le soufisme medieval." In Ethics and Spirituality in Islam: Sufi adab. Edited by Francesco Chiabotti, Eve Feuillebois-Pierunek, Catherine Mayeur-Jaouen, and Luca Patrizi, 198-215. Leiden: Brill, 2016.

Papas, Alexandre. Soufisme et politique entre Chine, Tibet et Turkestan: études sur les Khwajas Naqshbandis du Turkestan oriental. Paris: Jean Maisonneuve, 2005.

Papas, Alexandre. "Shaykh Succession in the Classical Naqshbandiyya: Spirituality, Heredity, and the Question of Body." Asian and African Studies 7, no. 1 (2007): 36-49.

Papas, Alexandre. "No Sufism without Sufi Order: Rethinking Tarīqa and Adab with Kāsānī Dahbidī (14611562)." Kyoto Bulletin of Islamic Area Studies 2, no. 1 (2008): 4-22.

Pocock, J. G. A. "On the Unglobality of Contexts: Cambridge Methods and the History of Political Thought." Global Intellectual History 4, no. 1 (2018): 1-14.

Potter, Lawrence G. "Sufis and Sultans in Post-Mongol Iran." Iranian Studies 27, no. 1/4 (1994): 77-102.

Reinert, Benedikt. "Ațțār, Farīd al-Dīn." Encyclopaedia Iranica Online, accessed June 4, 2019. Originally published in 1987. http://www. iranicaonline.org/articles/attar-farid-al-din-poet.

Rizvi, Sajjad H. "Before the Safavid-Ottoman Conflict: Jāmī and Sectarianism in Timurid Iran and Iraq." In Jāmì in Regional Contexts: The Reception of 'Abd al-Raḥmān Jāmī's Works in the Islamicate World, ca. 9th/15th-14th/20th Century. Edited by Thibaut d'Hubert and Alexandre Papas, 227-55. Leiden: Brill, 2018.

Salvatore, Armando. "The Euro-Islamic Roots of Secularity: A Difficult Equation." Asian Journal of Social Science 33, no. 3 (2005): 412-37.

Salvatore, Armando. "Notes on Locality, Connectedness, and Saintliness." In Dimensions of Locality: Muslim Saints, their Place and Space. Yearbook of the Sociology of Islam 8. Edited by Georg Stauth and Samuli Schielke, 89-100. Bielefeld: transcript Verlag, 2008.

Salvatore, Armando. "The Islamicate Adab Tradition vs. the Islamic Shari'a, from Pre-Colonial to Colonial." Working Paper Series of the HCAS "Multiple Secularities Beyond the West, Beyond Modernities” 3. Leipzig University, 2018.

Al-Sanhūtī, Yāsīn b. Ibrāhīm. Al-Anwār al-qudsiyyah fì manāqib al-sādah al-Naqshbandiyya, Cairo: Matba'at al-Sa'ada, 1925.

Al-Ṣarīfīnī, Ibrāhīm b. Muhammad, AlHalqah al-ūlā' min tārīkh Nìsābūr: al-muntakhab min al-siyāq ta'līf Abū Hasan 'Abd al-Ghāfir b. Ismā'īl al-Fārisī. Edited by Muhammad Kaẓim al-Maḥmudi. Qum: Jama'at al-Mudarrisin fi al-Hawzah al-'Ilmiyah, 1983.

Schamiloglu, Uli. "Tribal Politics and Social Organization in the Golden Horde." Unpublished PhD Dissertation, Department of History, Columbia University, 1986.

Schilling, Heinz. "Confessionalization: Historical and Scholarly Perspec- 
tives of a Comparative and Interdisciplinary Paradigm." In Confessionalization in Europe, 1555-1700: Essays in Honor and Memory of Bodo Nischan. Edited by John M. Headley, Hans J. Hillerbrand, and Anthony J. Papalas, 21-36. Aldershot, UK: Ashgate, 2004.

Schilling, Heinz. Early Modern European Civilization and its Political and Cultural Dynamism. Lebanon, NH: University Press of New England, 2008.

Schulze, Reinhard. "The Ambiguity of the Religious Self in Pre- and Postnational Social Worlds: Examples from $17^{\text {th }}$-Century Morocco and $20^{\text {th }}$-Century Germany." Paper presented at the $16^{\text {th }}$ Annual Conference of the European Association for the Study of Religions, Bern, June 17, 2018. http://www.easr2018. org/wp-content/uploads/2018/06/ Programmheft_final.pdf

Schulze, Reinhard. "Islam and the Global History of Secularity." Paper presented at the "Secularities - Patterns of Distinction, Paths of Differentiation" Conference, Leipzig, October 5, 2018. https://www.multiple-secularities.de/events/event/conference-secularities-patterns-of-distinction-paths-of-differentiation.

Al-Sha'rānī, 'Abd al-Wahhāb ibn Ahmad ibn 'Alī, In Advice for Callow Jurists and Gullible Mendicants on Befriending Emirs. Translated by Adam Sabra. New Haven: Yale University Press, 2017.

Sheehan, Jonathan. "Enlightenment, Religion and the Enigma of Secularization: A Review Essay." American Historical Review 108, no. 4 (2003): 1061-80.

Sibț ibn al-Jawzī, Shams al-Dīn Abū al-Muzaffar Yūsuf b. Qizughlī. Mir'āt al-zamān fī tā'rīkh al-a'yān, Edited by Salman al-Juburi. Beirut: Dar al-Kutub al-'Ilmiyya, 2013.
Stearns, Justin. "Writing the History of the Natural Sciences in the Pre-modern Muslim World: Historiography, Religion and the Importance of the Early Modern Period." History Compass 9, no. 12 (2011): 923-51.

Strathern, Alan. "Global Early Modernity and What Came Before." Past \& Present 238, no. 13 (2018): 317-44.

Subtelny, Maria E. "Kāšefi, Kamāl-alDin-Hosayn, Wā‘eẓ,” Encyclopaedia Iranica Online, accessed June 4, 2019. Originally published December 15, 2011. http://www.iranicaonline.org/articles/kasefi_kamal.

Ṭāhirī 'Irāqī Aḥmad. "Naqshī az Naqshbandiyān.” In Jashn nāma-i Muhammad Parwīn Gunābādī. Edited by Muhsin Abu al-Qasimi, 261-86. Tehran: Tus, 1975.

Ṭāhirī 'Iraqì, Aḥmad. Introduction to Qudsiyya by Khwāja Muhammad Pārsā-yi Bukhārā'ì. Edited by Ahmad Tahiri 'Iraqi, 9-120. Tehran: Tahuri, 1975.

Trevor-Roper, Hugh. The Crisis of the 17th Century: Religion, the Reformation and Social Change. Indianapolis: Liberty Fund, 1999.

Van Renterghem, Vanessa. "Les élites dans le monde arabo-musulman médiéval: l'exemple de Baghdad sous les Seldjoukides." Hypothéses 1 (2001): 77-85.

Werner, Christoph. "Die Schia in Iran: Von der Minderheit zur Mehrheit." In Religiöse Minderheiten und gesellschaftlicher Wandel. Edited by Edith Franke, 66-78. Wiesbaden: Harrassowitz, 2014.

Woods, John E. “Tīmūr's Genealogy.” In Intellectual Studies on Islam: Essays Written in Honor of Martin B. Dickson. Edited by Michel M. Mazzaoui and Vera B. Moreen, 85-125. Salt Lake City: University of Utah Press, 1990. 
Yavari, Neguin. Future of Iran's Past: Nizām al-Mulk Remembered. New York: Oxford University Press, 2018. Yavari, Neguin. "Deciphering Difference in Premodern Islamic Political Thought." In Origin, Transmission and Metamorphosis of the Concept of Adab. Edited by Catherine Mayeur Jaouen, Francesca Bellino, and Luca Patrizi. Leiden: Brill, forthcoming 2019.
Yavari, Neguin. "Sufis as Court Advisors." In Handbook of Sufi Studies: Sufi Institutions. Edited by Alexandre Papas. Leiden: Brill, forthcoming 2020.

Zadeh, Travis and Alya Karame. "The Art of Translation: An Early Persian Commentary on the Qur'ān." Journal of Abbasid Studies 2, no. 2 (2015): 119-95. 




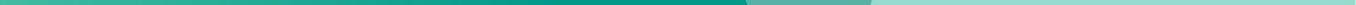

